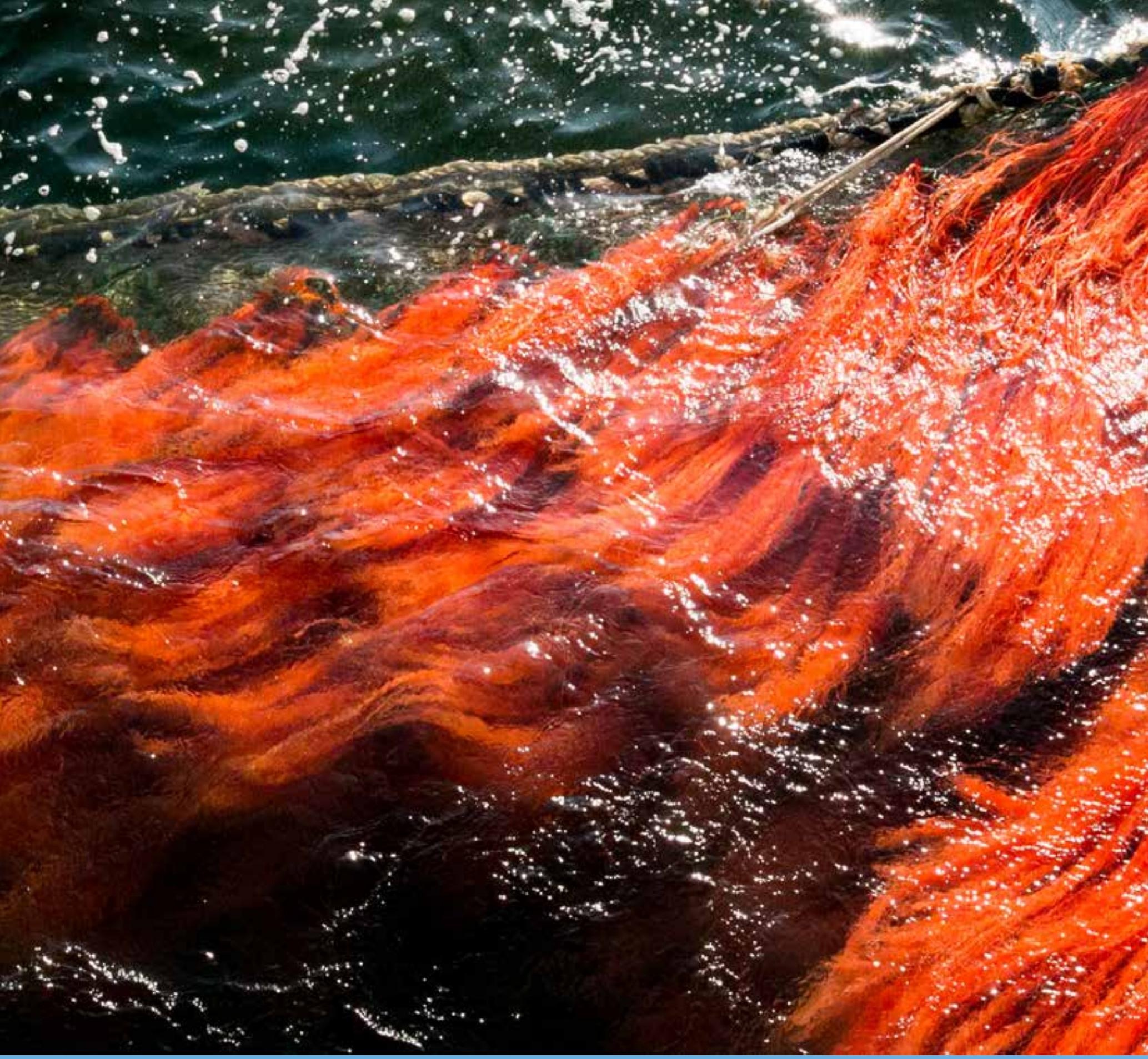

Eindrapportage VisPluisvrij

Activiteiten, resultaten en aanbevelingen op basis van de resultaten van het project

VisPluisvrij (2013-2018) en het aansluitende project 'Testfase Biopluis' in 2020

Strietman, W.J.

WAGENINGEN

UNIVERSITY \& RESEARCH 



\section{Eindrapportage VisPluisvrij}

Activiteiten, resultaten en aanbevelingen op basis van de resultaten van het project VisPluisvrij (2013-2018) en het aansluitende project 'Testfase Biopluis' in 2020

Strietman, W.J.

Dit onderzoek is uitgevoerd door Wageningen Economic Research en gesubsidieerd door het ministerie van Landbouw, Natuur en Voedselkwaliteit, in het kader van het Beleidsondersteunend onderzoeksthema Visserij (projectnummer BO-43-023.02-006)

Wageningen Economic Research

Wageningen, juni 2021

RAPPORT

2021-058

ISBN 978-94-6395-838-7 
Strietman, W.J., 2021. Eindrapportage VisPluisvrij; Activiteiten, resultaten en aanbevelingen op basis van de resultaten van het project VisPluisvrij (2013-2018) en het aansluitende project 'Testfase Biopluis' in 2020. Wageningen, Wageningen Economic Research, Rapport 2021-058. 30 blz.; 10 fig.; 0 tab.; 18 ref.

Het project VisPluisvrij is in 2013 gestart met als doel om oplossingen te ontwikkelen waarmee het verlies van pluis in zee substantieel verminderd kan worden. In dit rapport wordt een overzicht gegeven van de activiteiten en resultaten van het project van 2013 tot en met 2018 en van het aansluitende project ('Testfase Biopluis') dat in 2020 onder coördinatie van VisNed is uitgevoerd en op basis daarvan aanbevelingen gedaan voor vervolgstappen gedurende de komende periode.

Trefwoorden: pluis, vispluis, visserij, afval op zee, plastic soep

The DollyropeFree project was started in 2013 with the aim of developing solutions to substantially reduce the loss of dollyrope in the sea. This report provides an overview of the activities and results of the project from 2013 to 2018 and of the subsequent project ('Testfase Biopluis') that was carried out in 2020 under the coordination of VisNed, summarises the results of both projects and makes recommendations for follow-up steps during the coming period.

Key words: dollyrope, marine litter, Dutch fisheries, fishing gear, plastic soup

Dit rapport is gratis te downloaden op https://doi.org/10.18174/547773 of op www. wur. nl/economicresearch (onder Wageningen Economic Research publicaties).

(C) 2021 Wageningen Economic Research

Postbus 29703, 2502 LS Den Haag, T 07033583 30, E communications.ssg@wur.nl, www.wur.nl/economic-research. Wageningen Economic Research is onderdeel van Wageningen University \& Research.

\section{(cc) BY-NC}

Dit werk valt onder een Creative Commons Naamsvermelding-Niet Commercieel 4.0 Internationaallicentie.

(C) Wageningen Economic Research, onderdeel van Stichting Wageningen Research, 2021

De gebruiker mag het werk kopiëren, verspreiden en doorgeven en afgeleide werken maken. Materiaal van derden waarvan in het werk gebruik is gemaakt en waarop intellectuele eigendomsrechten berusten, mogen niet zonder voorafgaande toestemming van derden gebruikt worden. De gebruiker dient bij het werk de door de maker of de licentiegever aangegeven naam te vermelden, maar niet zodanig dat de indruk gewekt wordt dat zij daarmee instemmen met het werk van de gebruiker of het gebruik van het werk. De gebruiker mag het werk niet voor commerciële doeleinden gebruiken.

Wageningen Economic Research aanvaardt geen aansprakelijkheid voor eventuele schade voortvloeiend uit het gebruik van de resultaten van dit onderzoek of de toepassing van de adviezen.

Wageningen Economic Research is ISO 9001:2015 gecertificeerd.

Wageningen Economic Research Rapport 2021-058 | Projectcode 2282200516

Foto omslag: W.J. Strietman / Wageningen University \& Research 


\section{Inhoud}

Woord vooraf $\quad 5$

Samenvatting $\quad 6$

S.1 Resultaten en aanbevelingen $\quad 6$

$\begin{array}{lll}\text { S.2 Methodologie } & 7\end{array}$

$\begin{array}{ll}\text { Summary } & 8\end{array}$

$\begin{array}{lll}\text { S.1 Key results } & 8\end{array}$

S.2 Methodology $\quad 9$

$\begin{array}{lr}1 & 10\end{array}$

$\begin{array}{lll}1.1 & \text { Aanleiding voor het project VisPluisvrij } & 10\end{array}$

1.2 Het project VisPluisvrij 11

$\begin{array}{lll}1.3 & \text { Doelstelling } & 11\end{array}$

1.4 Leeswijzer $\quad 12$

$\begin{array}{ll}\text { Gebruik en verlies van pluis } & 13\end{array}$

2.1 Toepassing en gebruik 13

$\begin{array}{lll}2.2 & \text { Verlies van pluis in de visserij } & 15\end{array}$

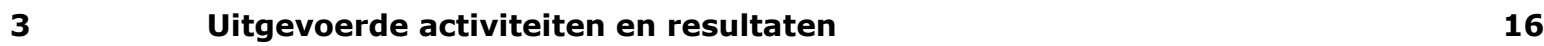

3.1 Vier oplossingsrichtingen 16

3.2 Het ontwikkelen van duurzame alternatieve materialen $\quad 16$

3.2.1 Activiteiten 16

3.2.2 Materiaal en ontwerp 17

3.2.3 Tests in de zeewatertank van het Visserij-innovatiecentrum en op
zee

3.2.4 Resultaten 19

3.3 Het ontwikkelen van alternatieve vormen van netbescherming 20

$\begin{array}{ll}3.3 .1 & \text { Inleiding } \\ & 20\end{array}$

3.4 Het ontwikkelen van manieren om bodemcontact te verminderen 21

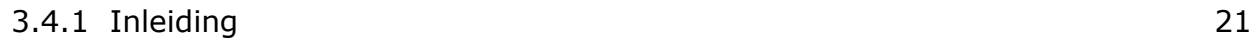

3.4.2 Aanpak, tests en huidige stand van zaken 21

3.5 Het creëren van bewustwording en vergroting van het draagvlak voor oplossingen

3.5.1 Inleiding $\quad 22$

3.5.2 Aanpak en resultaten $\quad 22$

$\begin{array}{lll}4.1 & \text { Inleiding } & 24\end{array}$

4.2 Het ontwikkelen van duurzame alternatieve materialen 24

4.2.1 Conclusie $\quad 24$

4.2.2 Aanbeveling $\quad 25$

4.3 Het ontwikkelen van alternatieve vormen van netbescherming 25

4.3.1 Conclusie $\quad 25$

4.3.2 Aanbeveling $\quad 25$

4.4 Het ontwikkelen van manieren om het bodemcontact te verminderen 25

4.4.1 Conclusie $\quad 25$

4.4.2 Aanbeveling $\quad 25$ 
4.5 Het creëren van bewustwording en de vergroting van het draagvlak voor oplossingen

4.5.1 Conclusie

26

4.5.2 Aanbeveling

26

4.6 Aansluiting op relevante beleidsontwikkelingen

26

4.6.1 Aanbeveling

27

Literatuur en websites 


\section{Woord vooraf}

Deze eindrapportage is het sluitstuk van de periode waarin vanuit allerlei organisaties, bedrijven en visserij ondernemers activiteiten zijn uitgevoerd om het verlies van pluis in zee substantieel te verminderen. Deze activiteiten vonden tussen 2013 tot en met 2018 plaats vanuit het project VisPluisvrij onder coördinatie van Wing en later Wageningen Economic Research, en in 2020 vanuit van het aansluitende project 'Testfase Biopluis', dat onder coördinatie van VisNed is uitgevoerd.

Het project VisPluisvrij is in 2013 gestart op initiatief van Wing, VisNed, Stichting De Noordzee en Rijkwaterstaat. Daarna heeft ook het ministerie van LNV zich bij deze stuurgroep gevoegd.

De uitvoering van de activiteiten binnen VisPluisvrij was niet mogelijk geweest zonder de vrijwillige inzet van de betrokken visserijondernemers, de inzet van medewerkers van de betrokken organisaties, de inzet en investeringen van de betrokken materiaalproducenten en de financiële bijdragen van Rijkswaterstaat, het ministerie van LNV, St. De Noordzee en de Stichting Verduurzaming Visserijsector Voordelta.

Aan allen die in wat voor vorm dan ook bij het project betrokken zijn geweest, zijn de initiatiefnemers dan ook grote dank verschuldigd. In het bijzonder zijn dat de schippers en bemanningen van de zeven betrokken kotters, zonder wie de tests op zee niet mogelijk zouden zijn geweest en het VisserijInnovatiecentrum Zuidwest-Nederland voor het uitvoeren en van de tests in de zeewatertank van het innovatiecentrum en de coördinatie van de tests op zee in fase 6. Ook zijn dat de materiaalproducenten Senbis, Modified Materials, Peter Koning, Herikon en Ymuiden Stores, die allen een belangrijke bijdrage geleverd hebben aan de (door)ontwikkeling van de te testen materialen en het nadenken over oplossingen om deze materialen te perfectioneren. Daarnaast danken we ook de leden van de stuurgroep van VisPluisvrij voor hun inzet en toewijding om dit project tot een succes te maken: VisNed, Stichting De Noordzee, Rijkswaterstaat en het ministerie van Landbouw, Natuur en Voedselkwaliteit.

Met de afronding van de in dit rapport beschreven activiteiten, zijn voor de betrokken stakeholders oplossingen in kaart gebracht om de komende jaren het verlies van pluis in zee substantieel te verminderen. Wij wensen alle betrokkenen succes toe om, vanuit de gedachte van VisPluisvrij, deze uitdaging in gezamenlijkheid op te pakken en te realiseren.

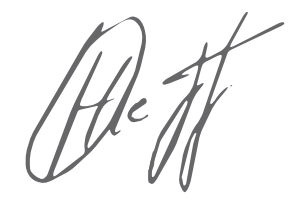

Ir. O. (Olaf) Hietbrink

Business Unit Manager Wageningen Economic Research

Wageningen University \& Research 


\section{Samenvatting}

\section{S.1 Resultaten en aanbevelingen}

In dit rapport worden de resultaten van zowel het project VisPluisvrij als het aansluitende project 'Testfase Biopluis' samengevat en op basis daarvan aanbevelingen geformuleerd. Deze worden hieronder per thema nader toegelicht:

\section{Het ontwikkelen van duurzame alternatieve materialen}

Een belangrijke focus in het project VisPluisvrij was de ontwikkeling van alternatieve materialen die duurzamer zijn dan regulier pluis. Op basis van tests in de praktijk zijn veel opties afgevallen maar ook een aantal kansrijke oplossingen overgebleven. Zo kunnen bijvoorbeeld strips van jakleer en kunstrubber goed ingezet worden als alternatief voor regulier pluis op zandige visgronden. Draden van zogenaamd 'Biopluis' is nog in ontwikkeling maar leek op basis van de eerste tests goede resultaten te geven. Na afronding van het project VisPluisvrij in 2018 zijn er onder coördinatie van VisNed in 2020 extra tests uitgevoerd met dit materiaal. Hieruit bleek dat dit goed werkt bij toepassing op zowel zandige als stenige visgronden onder de voorwaarde dat het materiaal stevig onder het net bevestigd kan worden en aan boord beschermd opgeslagen kan worden. Van zowel het jakleer als het Biopluis is de kostprijs in vergelijking met regulier pluis wel substantieel hoger dan regulier pluis. De aanbeveling is om vanuit de overheid en de sectororganisaties het gebruik van deze en soortgelijke duurzame alternatieven te stimuleren en vanuit de overheid naar mogelijkheden te zoeken om de sector in het geval van hogere marktprijzen financieel tegemoet te komen.

\section{Het ontwikkelen van alternatieve vormen van netbescherming}

Bij dit projectonderdeel kwam één specifieke oplossing naar voren die een waardevol alternatief lijkt te kunnen zijn voor regulier pluis bij gebruik in de tongvisserij door eurokotters in de kustzone: een soort beschermingsnet met grote mazen die om het uiteinde van het net bevestigd kan worden en gemaakt is van touwen omhuld door rubberen slangen en kabelschijfjes. Een nog openstaande vraag is of deze oplossing ook toepasbaar is en naar wens werkt bij garnalenvisserij in de kustzone, bij garnalenvisserij op de Waddenzee en bij de platvisvisserij met grote kotters in diepere wateren. De aanbeveling is om vanuit de sector in overleg met Rijksdienst Voor Ondernemend Nederland (RVO) en het Ministerie van Landbouw, Natuur en Voedselkwaliteit (LNV) en Wageningen University \& Research te bepalen of vervolgtests hiermee mogelijk zijn. Daarmee kan bepaald worden onder welke omstandigheden (type visserij, waterdiepte) deze oplossing effectief en haalbaar is.

\section{Het ontwikkelen van manieren om het bodemcontact van het net te verminderen}

Gedurende de projectperiode zijn verschillende soorten oplossingen onder de loep genomen om het bodemcontact van het net te verminderen. De conclusie luidde dat er kansen lagen om deze ideeën te testen en toepasbaar te maken voor gebruik in de visserij maar dat hiervoor vervolgstappen voor nodig waren met meer betrokkenen en financiers. Na overleg met stakeholders in Duitsland is deze oplossingsrichting daar verder opgepakt door het Thünen Instititut en heeft geresulteerd in het project 'Dolly Rope Suspension' (DropS). Binnen dit project wordt momenteel gewerkt aan verschillende oplossingen die kunnen helpen het bodemcontact van garnalennetten te minimaliseren zonder de vangst negatief te beïnvloeden. Het project is nog in uitvoering en aanbevelingen worden verwacht nadat de tests zijn uitgevoerd.

\section{Het creëren van bewustwording en de vergroting van het draagvlak voor oplossingen}

Sinds 2013 zijn door de bij dit project betrokken partijen allerlei communicatieactiviteiten uitgevoerd om de bewustwording rondom het probleem van pluis en de oplossingen ervoor te vergroten. Voorbeelden hiervan zijn het betrekken van vissers door deelname aan de tests en het delen van ervaringen in overleggen, informatieverspreiding en kennisdeling via websites, nieuwsartikelen, presentaties over het project en aanwezigheid bij (visserij)evenementen zoals Holland Fisheries Event. Daarnaast hebben de bij VisPluisvrij betrokken partners zich ervoor ingezet om binnen de Green Deal 
Visserij voor een Schone Zee acties op te zetten met als doel de verzameling en opslag van afval aan boord (inclusief pluis) en de afgifte ervan in havens te verbeteren. De aanbeveling aan de voormalige projectpartners van VisPluisvrij is om het thema pluis en de oplossingen ervoor te blijven adresseren binnen de Green Deal, binnen de sector in brede zin, bij producenten, coöperaties en het brede publiek. Ook is de aanbeveling richting producenten en coöperaties hierin een actieve rol te nemen.

De komende jaren spelen er een aantal belangrijke beleidsontwikkelingen die raken aan het gebruik van pluis en de inzet van alternatieven: het ontwerpprogramma van maatregelen van de Kaderrichtlijn Mariene Strategie (met daarin een voorgestelde uitfasering van pluis richting 2027), de Single Use Plastics Richtlijn (EU), het standaardisatietraject rondom vistuig (Nederland en EU) en het OSPAR Regional Action Plan. Het is de aanbeveling om in het kader van deze beleidstrajecten een klankbordgroep op te richten die kan adviseren over de invulling, aanpak en waar nodig begeleiding bieden van de voorziene maatregelen, bestaande uit coöperaties en sectorvertegenwoordigers, overheid, onderzoek en NGO's.

\section{S.2 Methodologie}

Het project VisPluisvrij is in 2013 gestart op initiatief van VisNed, St. De Noordzee, Rijkwaterstaat en Wing met als doel om in gezamenlijkheid oplossingen te ontwikkelen waarmee het verlies van pluis in zee substantieel verminderd wordt. Het project werd in eerste instantie uitgevoerd onder coördinatie van Wing en later van Wageningen Economic Research. Het project bestond uit zes verschillende fasen die samen één geheel vormden. De laatste fase, fase zes, eindigde in 2018. Aansluitend is in 2020 onder coördinatie van VisNed het project 'Testfase Biopluis' gestart, waarin door vijf kotters op zee aanvullende tests uitgevoerd zijn met in zeewater afbreekbare biopolymeren.

De basis voor dit rapport vormen de resultaten en conclusies van zowel de rapporten van alle VisPluisvrij fasen (1-6) als die van het aansluitende VisNed-project ('Testfase Biopluis'). In dit rapport zijn deze samengevat en op grond daarvan worden aanbevelingen gedaan voor de komende periode. 


\section{Summary}

\section{S.1 Key results}

This report summarises the results of both the DollyropeFree project and the subsequent 'Test Phase Bio-Dollyrope' project and formulates recommendations based on this. These are further explained per theme below:

\section{Developing sustainable alternative materials}

An important focus in the DollyropeFree project was the development of alternative materials that are more environmentally friendly than regular dollyrope. On the basis of tests in practice, many options have been dropped, but also a number of promising solutions have remained. For example, strips both made of yak leather and synthetic rubber can be used as an alternative to regular dollyrope on sandy fishing grounds. Threads made from 'Bio-Dollyrope' as an alternative material is still under development but seemed to give good results based on the first tests. After the completion of the VisPluisvrij project in 2018, additional tests were carried out with this material in 2020 under the coordination of VisNed. This showed that the material works well when used on both sandy and stony fishing grounds, provided that the material can be securely fastened under the net and stored on board in a protective environment (to prevent bio-degradation). The cost price of both the yak leather and 'Bio-Dollyrope' compared to regular dollyrope is substantially higher than regular dollyrope. The recommendation for the sector organisations and fisheries cooperatives is to stimulate the use of these sustainable alternatives and for the government to look for possibilities to provide the sector with financial support in the event of higher market prices in comparison to regular dollyrope.

\section{Alternative forms of grid protection}

In this project part, one specific solution emerged that appears to be a valuable alternative to regular dollyrope when used in sole fishing by 'euro cutters' (smaller beam trawlers) in the coastal zone: a type of large mesh protection net that can be attached and wrapped around the end of the net and which consists of ropes covered by rubber hoses and cable pulleys. An open question is whether this solution can also be applied in shrimp fisheries in the coastal zone, shrimp fisheries in the Wadden Sea and flatfish fisheries with larger beam trawlers in deeper waters. The recommendation for the sector organisations is to consult with the Netherlands Enterprise Agency (RVO) and the Ministry of Agriculture, Nature and Food Quality and Wageningen University \& Research whether follow-up tests are possible to determine in which circumstances (fishing sector, water depth) this solution would be effective and feasible.

\section{Developing ways to reduce the ground contact of the net}

During the project period, various types of solutions were examined to reduce or prevent the contact of the gear with the seabed, thus making the use of dolly ropes as abrasion protection superfluous. The conclusion was that there were opportunities to test these ideas and make them applicable for use in fisheries, but that this required follow-up steps with more stakeholders and funders. After consultation with stakeholders in Germany, this solution was taken up there further by the Thünen Institute and resulted in the project 'Dolly Rope Suspension' (DropS). Within this project, various solutions are being developed that can help minimise the bottom contact of shrimp nets without negatively affecting the catch. The project is still in progress and recommendations are expected after the tests have been carried out.

\section{Creating awareness and increasing support for solutions}

Since 2013, the organisations involved in the DollyropeFree project have carried out all kinds of communication activities to increase awareness of the dollyrope problem and the solutions to it. Examples include the involvement of fishermen by participating in the tests and sharing experiences in meetings, dissemination of information and knowledge through websites, news articles, presentations about the project and presence at (fishing) events such as Holland Fisheries Event. In addition, the 
organisations involved in the DollyropeFree project have committed themselves to initiate actions within the context of the Fisheries for a Clean Sea Green Deal covenant with the aim of improving the collection and storage of waste on board (including dollyrope) and its delivery in ports. The recommendation to the project partners of the DollyropeFree project is to continue to address the issue of dollyrope and the need for solutions to fishers, producers, cooperatives and the general public. It is also recommended that producers and cooperatives take an active role in this.

In the coming years, a number of important policy developments will affect the use of dollyrope and the need for the deployment of more environmentally friendly alternatives: the draft Dutch programme of measures of the Marine Strategy Framework Directive (which includes a proposed phasing out of dollyrope by 2027), the Single Use Plastics Directive (EU), the standardisation process of fishing gear (the Netherlands and EU) and the OSPAR Regional Action Plan. The recommendation is to set up an advisory group consisting of cooperatives and sector representatives, government, research and NGOs that can advise on the implementation, approach and, where necessary, offer guidance for the measures envisaged.

\section{S.2 Methodology}

The DollyropeFree project was started in 2013 on the initiative of VisNed, St. De Noordzee, Rijkwaterstaat and Wing with the aim of jointly developing solutions that substantially reduce the loss of dollyrope at sea. The project was initially carried out under the coordination of Wing and later of Wageningen Economic Research. The project consisted of six subsequent phases. The last phase, phase six, ended in 2018. Subsequently, in 2020, under the coordination of VisNed, a project was started in which five bottom-trawling vessels carried out additional tests with a material made from polymers that biodegrade in seawater ('Test Phase Bio-Dollyrope').

The basis for this report is formed by the findings and results decribed in the reports of the DollyropeFree project phases (1-6) as well as those in the report of the subsequent VisNed project 'Test phase Biopluis'. These findings and results have been summarised in this report, based on which recommendations are provided for the coming period. 


\section{$1 \quad$ Inleiding}

\subsection{Aanleiding voor het project VisPluisvrij}

Vispluis, ook wel 'pluis' genoemd, is de naam van de oranje of blauwe plastic draadjes die in trossen onder visnetten bij de bodemvisserij (onder andere op schol, tong en garnalen) geplaatst worden. De trossen plastic draden werken hierbij als een buffer tussen de bodem en het net waardoor het net beschermd wordt tegen slijtage, het pluis slijt echter wel. Zowel door deze slijtage als door onderhoudswerkzaamheden aan het net komt pluis in zee terecht.

Pluis is gemaakt van polyethyleen (HDPE), een type plastic. Dit betekent onder andere dat pluis niet biologisch kan worden afgebroken. Naarmate de tijd verstrekt zal dit materiaal onder invloed van de elementen op den duur uiteenvallen in steeds kleinere stukjes plastics, ook wel micro-plastics genoemd. Voordat het uiteenvalt, kunnen vogels en andere zeedieren verstrikt raken in het pluis en draagt aangespoeld pluis bij aan de vervuiling van stranden. Daarnaast kunnen grotere plukken ronddrijvend pluis een risico opleveren voor de scheepvaartveiligheid, in het geval die plukken terechtkomen in een scheepsschroef. Een ander nadeel is dat losse pluisdraden tijdens het vissen in de netten en op andere plekken op het schip terechtkomen. Het verwijderen hiervan, met name uit de visnetten, kan veel tijd kosten.

Dat er jaarlijks veel pluis in zee terechtkomt wordt bevestigd door de monitoringsgegevens van OSPAR op basis van periodieke tellingen van afval op Nederlandse stranden (vier locaties langs de kust). Op de monitoringsstranden vormt pluis samen met ander visserij gerelateerd afval zoals stukken net en touw het tijdens tellingen meest gevonden type zwerfafval uit zee (gemiddeld liggen er op deze locaties 95 stuks pluis per 100 meter strand (Boonstra et al., 2021). In de periode 2001-2020 blijkt er een significante dalende trend geweest te zijn in de hoeveelheden pluis die aangetroffen wordt. De oorzaak is niet één-op-één te bepalen, maar zou te maken kunnen hebben met de verkleining van de vloot, de overgang naar pulsvisserij (minder gebruik van pluis dan de boomkorvisserij met wekkerkettingen) en initiatieven vanuit de sector en andere betrokkenen om het afvalmanagement aan boord en in de havens te verbeteren.

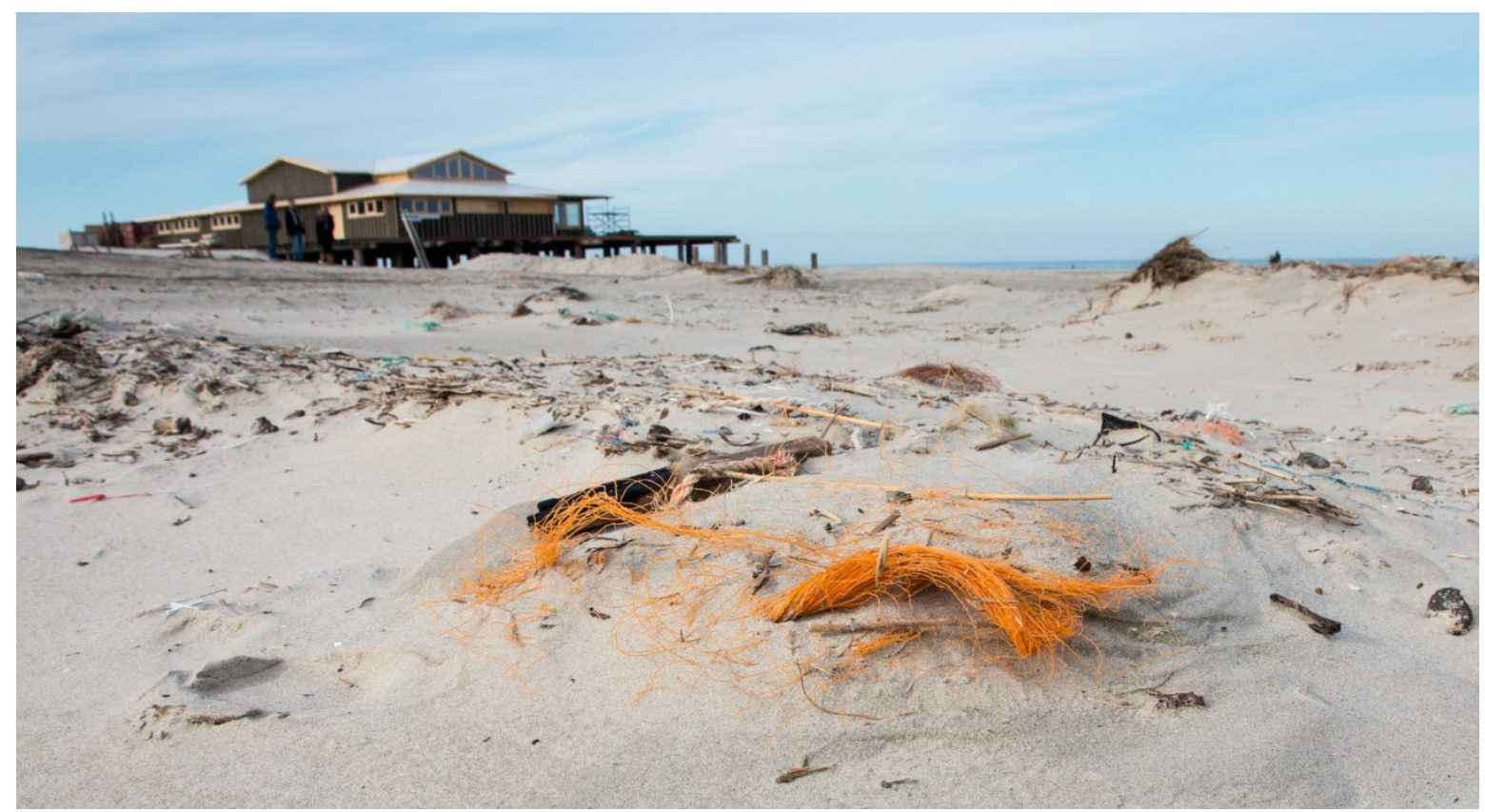

Figuur 1.1 Aangespoeld pluis op het strand van Terschelling

Foto: W.J. Strietman. 


\subsection{Het project VisPluisvrij}

Het project VisPluisvrij is in 2013 gestart op gezamenlijk initiatief van Stichting De Noordzee, VisNed, Rijkswaterstaat Zee \& Delta en Wing. De directe aanleiding was de hoeveelheid pluis die tijdens strandmonitoring op de stranden gevonden werd en de wens van alle betrokkenen om het tij wat dit betreft te keren. Het gezamenlijke doel was om de handen ineen te slaan en constructief samen te werken aan oplossingen om de hoeveelheid pluis die jaarlijks vanuit de Nederlandse bodemvisserij in zee terechtkomt substantieel te verminderen.

Het project is in eerste instantie uitgevoerd onder coördinatie van Wing en later Wageningen Economic Research. Het project bestond uit zes verschillende fasen die samen één geheel vormden. De laatste fase, fase zes, eindigde in 2018. Binnen VisPluisvrij is gewerkt aan de volgende vier oplossingsrichtingen:

1. Het ontwikkelen van duurzame alternatieve materialen

2. Het ontwikkelen van alternatieve vormen van netbescherming

3. Het ontwikkelen van manieren om bodemcontact van het net te verminderen

4. Het creëren van bewustwording en vergroting van het draagvlak voor oplossingen.

Aansluitend op VisPluisvrij is in 2020 onder coördinatie van VisNed een project gestart waarin door vijf kotters op zee tests uitgevoerd zijn met in zeewater afbreekbare biopolymeren als vervolg op de tests die in fase 6 vanuit VisPluisvrij in samenwerking met het Visserij-Innovatiecentrum Zuidwest waren uitgevoerd.

Kennisuitwisseling en innovatie hebben sinds de start van het project centraal gestaan. VisPluisvrij heeft daarbij gediend als platform voor bedrijven, individuen en organisaties om ideeën uit te wisselen en alternatieven (door) te ontwikkelen tijdens tests in de praktijk. Voor dit laatste onderdeel zijn er in samenwerking met het Visserij-Innovatiecentrum Zuidwest en schippers en bemanningen van verschillende vissersschepen tests uitgevoerd met potentieel kansrijke materialen en ontwerpen.

Wing en later Wageningen Economic Research hebben gedurende de projectperiode opgetreden als procesfacilitator en coördinator, waarbij VisNed, Stichting De Noordzee, het ministerie van Landbouw, Natuur en Voedselkwaliteit (LNV) en Rijkswaterstaat deelnamen aan de stuurgroep. Aansluitend op het project VisPluisvrij heeft VisNed in 2020 via een vervolgproject aanvullende tests gecoördineerd. Gedurende de looptijd van VisPluisvrij hebben allerlei andere organisaties, bedrijven en individuen hun expertise en medewerking verleend, in het bijzonder de bemanning van verschillende kotters, het Visserij-innovatiecentrum Zuidwest-Nederland, door Senbis Polymer Innovations BV (hierna afgekort als Senbis), Modified Materials, Ymuiden Stores, Peter Koning en Herikon.

Met als doel om te leren van de ervaringen opgedaan in het project VisPluisvrij en het recente aansluitend testproject uitgevoerd door VisNed te bepalen wat passende vervolgstappen zijn, heeft het ministerie van LNV aan Wageningen Economic Research opdracht gegeven om in deze eindrapportage een overzicht te geven van de activiteiten en resultaten van 2013 tot en met 2021 en op basis daarvan aanbevelingen te formuleren.

\subsection{Doelstelling}

Dit rapport heeft als doelstelling een overzicht te geven van de activiteiten en resultaten van het project VisPluisvrij van 2013 tot en met 2018, de aansluitende tests onder coördinatie van VisNed en het lopende project DRopS van het Thünen Insititut en op basis daarvan aanbevelingen te formuleren voor vervolgstappen in de periode 2022-2027. 


\subsection{Leeswijzer}

Hoofdstuk 2 gaat nader in op de vraag wat pluis is, hoe het gebruikt wordt en waardoor er verlies van pluis op zee ontstaat. In hoofdstuk 3 worden de uitgevoerde activiteiten en resultaten beschreven van het project VisPluisvrij en het aansluitende project 'Testfase Biopluis', aan de hand van de vier oplossingsrichtingen in die projecten. In hoofdstuk 4 worden op basis van de conclusies de aanbevelingen voor vervolgstappen geformuleerd. 


\section{Gebruik en verlies van pluis}

\section{$2.1 \quad$ Toepassing en gebruik}

Pluis bestaat uit oranje of blauwe polyethyleen draadjes die in trossen bevestigd worden onder het netwerk van bodemsleepnetten om deze te beschermen tegen slijtage (zie figuur 2.1).

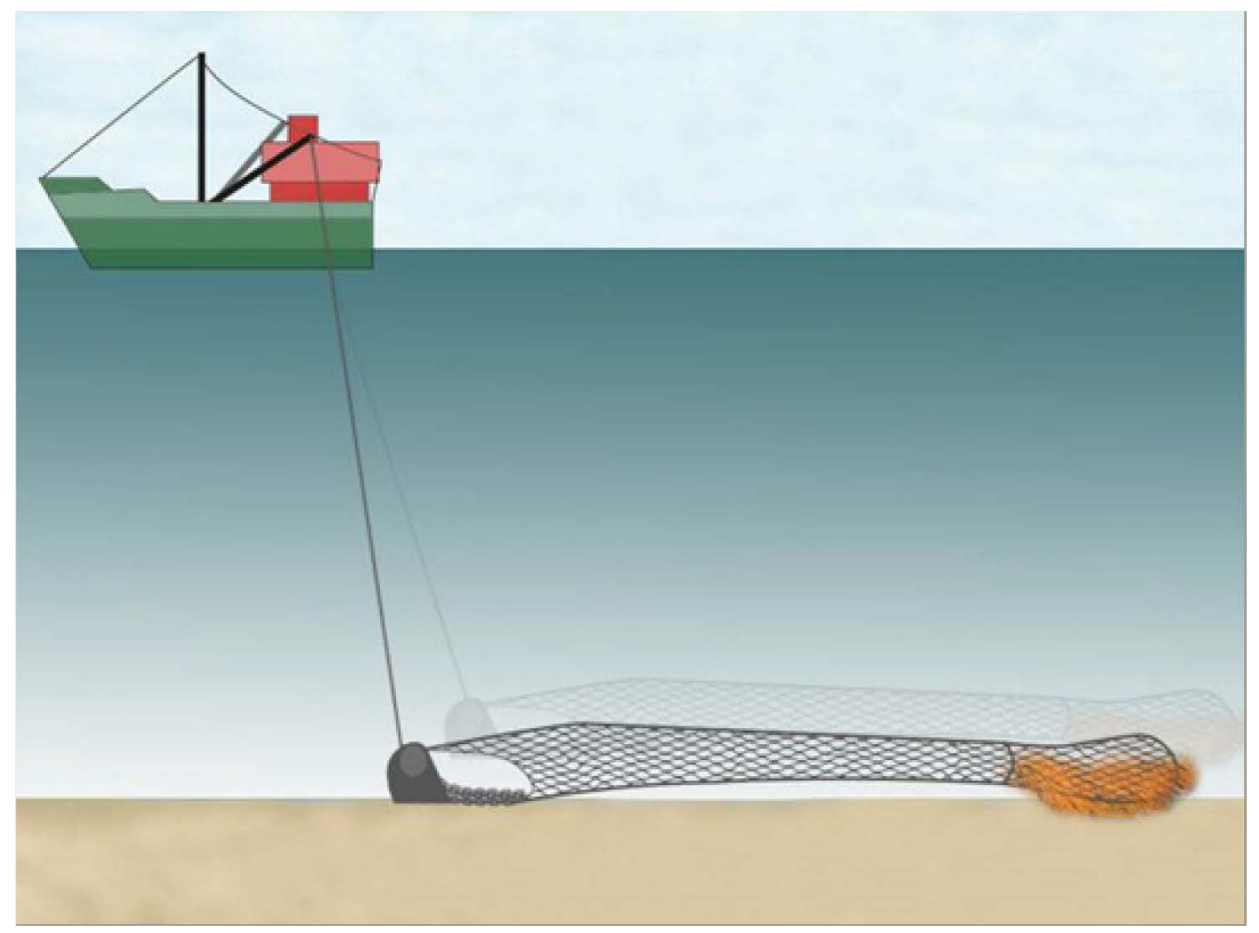

Figuur 2.1 Vereenvoudigde weergave van de locatie van pluis onder een visnet Bron: Wing (gepubliceerd in Strietman et al., 2013).

Pluis is gemaakt van polyethyleen, een kunststof dat niet in zeewater afbreekt. Dit materiaal wordt geleverd als touw, op rollen van ongeveer 22 kilo (figuur 2.2). Dit touw bestaat uit 30 koorden van elk 25 draadjes die los om elkaar heen gedraaid zijn (750 draadjes per touw). Dit wordt in stukken van 60-100 cm lengte gesneden en met een tussenafstand van $10 \mathrm{~cm}$ onder het net en/of sleeplap bevestigd (figuur 2.2) (Strietman, 2020).
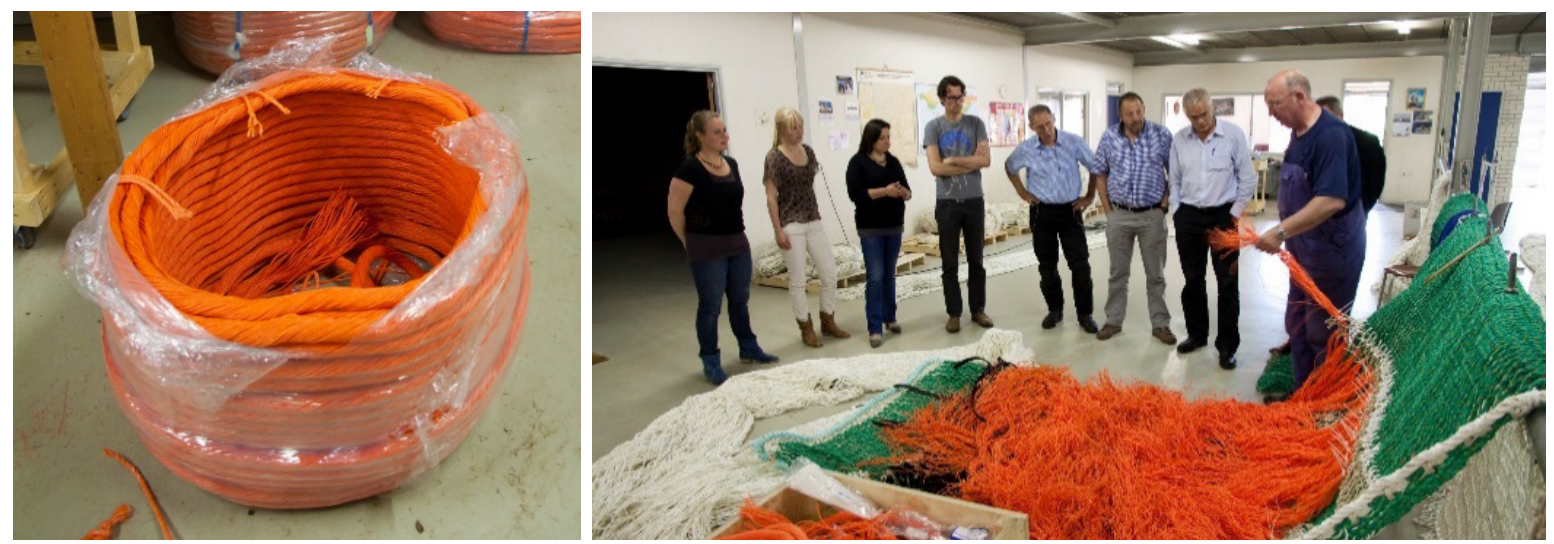

Figuur 2.2 Een nieuwe rol pluis (links) en de manier waarop pluis aan het net bevestigd wordt (rechts) Foto's: W.J. Strietman. 
Per schip en visserij verschilt de hoeveelheid pluis die onder een net bevestigd wordt. Uit gesprekken met verschillende visserijondernemers bleek dat er geen eenduidig beeld over de toegepaste hoeveelheid pluis per net naar voren komt omdat de situaties waarin pluis gebruikt wordt verschilt per type visserij maar ook per gebied en zelfs per dag. Zo wordt er bijvoorbeeld in gebieden met meer kans op slijtage (steenachtige zeebodem) meer pluis onder de netten bevestigd dan onder netten die gebruikt worden op zandige bodems (Strietman et al., 2013).

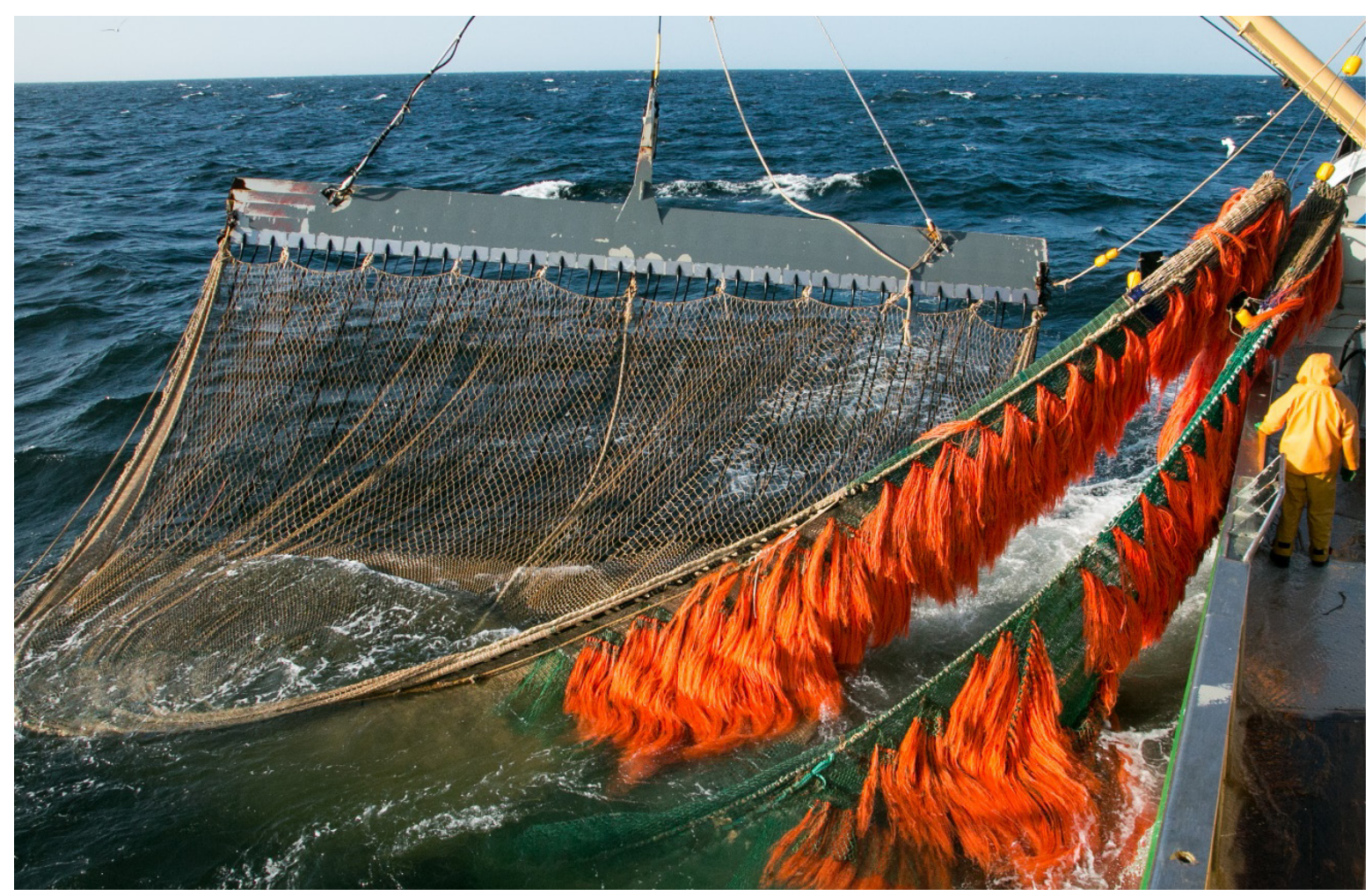

Figuur 2.3 Gebruik van pluis onder een Nederlands pulskornet. Op deze foto hangt het uiteinde van het net (de kuil) uit het water. Aan de onderkant daarvan is het pluis bevestigd Foto: W.J. Strietman.

Uit gesprekken met vissers tijdens het project VisPluisvrij kwam naar voren dat het gebruik van pluis flink is toegenomen sinds de jaren tachtig, toen de maaswijdte voor tong verruimd werd van 70 millimeter naar 80 millimeter. Het gevolg daarvan was dat er meer maatse (legale minimale lengte) kleine tong door de mazen glipte, met name tijdens het vissen in diepere wateren (20-30 meter diepte) waar er in het net meer druk wordt uitgeoefend op de vis en daarmee de kans op ontsnappen vergroot wordt. Naast dat pluis primair bedoeld is om slijtage te voorkomen, kan de toepassing ervan ook een deel van dergelijk verlies voorkomen.

In Europa wordt, vooral in de zuidelijke Noordzee, het Kanaal, de Ierse Zee en de Golf van Biskaje, pluis gebruikt. Het grootste deel wordt gebruikt door de Nederlandse en Belgische bodemvissers op tong, schol en garnalen. Een grove schatting van de jaarlijkse Europese verkoop van nieuw pluis betrof in 2013 ongeveer 100.000 kilo, waarvan 40.000 kilo door Nederlandse vissers werd aangekocht (Strietman et al., 2013 en Strietman, 2013). 


\subsection{Verlies van pluis in de visserij}

Een pluistouw bestaat uit enigszins los van elkaar zittende koorden en draadjes. Zodra er gestart wordt met vissen, ontrafelen die koorden en draadjes zich snel en spreiden zich als het ware als een waaier uit. Deze vormt een soort deklaag die (de mazen van) het net afschermt en het net beschermt tegen slijtage in het geval die over zand of stenen schuurt.

Pluis werkt als een soort buffer tussen bodem en net. Indien het net (met pluis eronder) schuurt over de bodem, dan kunnen er pluisdraadjes of kluwen pluisdraadjes loskomen. Een visnet zal echter niet uit zichzelf over de bodem gaan schuren. In tegenstelling tot wat veel mensen denken is daarvan de reden niet zozeer dat het net vol kan zitten met vis waardoor het naar beneden gedrukt wordt. Vis is in water immers min of meer gewichtloos en zal daarom niet 'zwaar worden' en zo het net naar beneden drukken. Er zijn dus andere redenen waarom er slijtage kan optreden. Deze zijn als volgt:

1. Tijdens het vissen kunnen er door de netopening aan de voorkant zand en stenen het net binnenkomen en het net daardoor naar beneden drukken;

2. De vorm van het net kan in sommige gevallen tot meer bodemcontact leiden;

3. Tijdens het vissen kan het net over richels, stenen of andere obstakel getrokken worden.

Gedurende deze eerste twee maanden slijt er hierdoor ongeveer 10-25\% weg. Tegelijkertijd verklitten de resterende draadjes zich steeds meer (figuur 2.4) (Strietman et al., 2013).
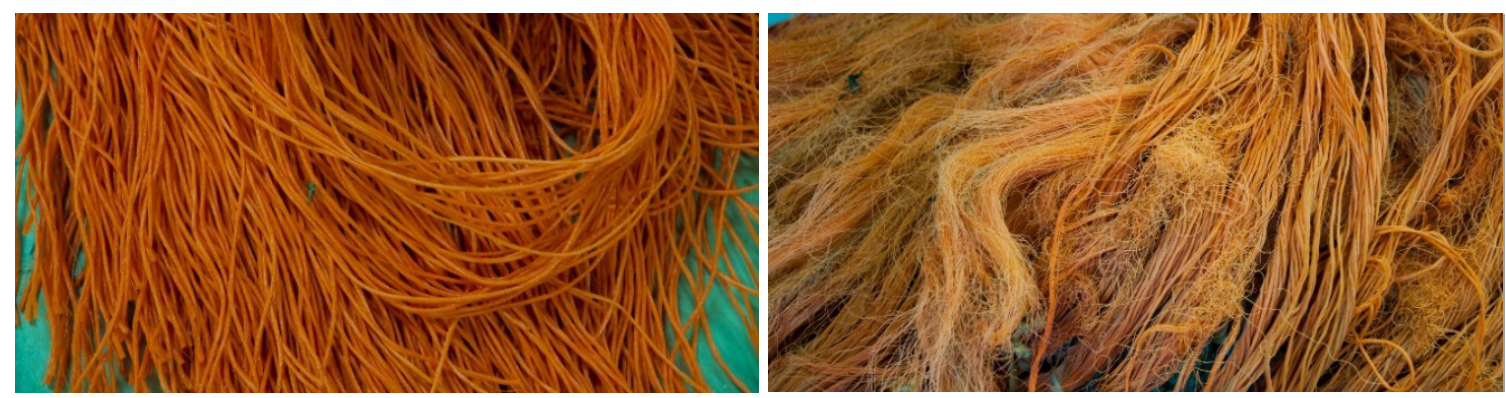

Figuur 2.4 Nieuw bevestigd pluis (links) en pluis na twee maanden gebruik (rechts) Foto's: W.J. Strietman.

Door het proces van verklitting komen er steeds minder pluisdraadjes los, maar verliest het pluis ook zijn flexibiliteit. Daarnaast blijven er in het verklitte pluis gemakkelijk zand en kleine steentjes achter, wat het net ongewenst zwaarder maakt. Hierdoor verliest pluis na ongeveer twee maanden zijn oorspronkelijke werking en wordt dan ook over het algemeen vervangen (figuur 2.5). Indien dit niet tijdig verzameld en aan boord opgeslagen wordt, kan dit in zee belanden. Dit extra verlies is (naast slijtage van 10-25\%) in 2013 door vissers ingeschat op maximaal 25\% (Strietman et al., 2013). Met deze ingeschatte percentages zal het totale jaarlijks verlies in Europa in 2013 gelegen hebben ergens tussen de 10.000 en 50.000 kilo, waarvan in Nederland tussen de 4.000 en 12.500 kilo.

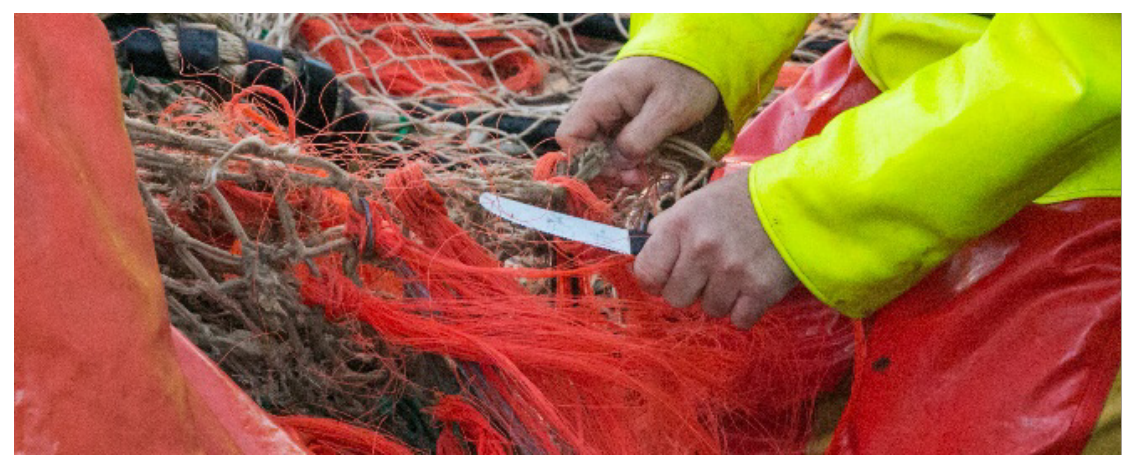

Figuur 2.5 Onderhoudswerkzaamheden aan pluis Foto: W.J. Strietman. 


\section{$3 \quad$ Uitgevoerde activiteiten en resultaten}

\subsection{Vier oplossingsrichtingen}

Binnen VisPluisvrij is gedurende de projectperiode gewerkt aan de volgende vier oplossingsrichtingen:

1. Het ontwikkelen van duurzame alternatieve materialen

2. Het ontwikkelen van alternatieve vormen van netbescherming

3. Het ontwikkelen van manieren om het net te liften

4. Het creëren van bewustwording en vergroting van het draagvlak voor oplossingen.

In de hierop volgende paragrafen gaan we inhoudelijk nader in op de activiteiten en resultaten van deze vier oplossingsrichtingen.

\subsection{Het ontwikkelen van duurzame alternatieve materialen}

\subsubsection{Activiteiten}

Het doel van dit projectonderdeel is om betaalbare milieuvriendelijk(er)e materialen te ontwikkelen die gebruikt kunnen worden ter vervanging van regulier pluis, waardoor er minder pluis in zee terechtkomt en/of de milieueffecten substantieel lager zijn. Hierbij gaat het om het vinden of ontwikkelen van duurzamere materialen en de vorm waarin dit wordt toegepast (bijvoorbeeld draden of flappen), al of niet in combinatie met elkaar.

De zoektocht naar een duurzaam alternatief voor regulier pluis bestaat uit een trechterproces: in 2013 is er gestart met een proces om zoveel mogelijk bruikbare ideeën te verzamelen. Met de kritische blik van betrokkenen binnen en buiten de sector zijn er tijdens dit trechterproces meer dan twintig soorten materialen en ontwerpen geselecteerd, ontwikkeld of doorontwikkeld en in opdracht van het project VisPluisvrij getest in de zeewatertank van het Visserij-innovatiecentrum Zuidwest-Nederland en in de praktijk door schippers en bemanningen van zeven kotters. Wat die tests uniek maakte, was dat alle materialen in de geteste vorm nog niet eerder (onder extreme omstandigheden) op zee getest waren.

Bij het verzamelen van ideeën is gebruikgemaakt van crowdsourcing, zowel offline als online:

- Om ideeën te verzamelen en verder te ontwikkelen zijn er gedurende de projectperiode ongeveer 10 expertsessies georganiseerd. Daarbij zijn alle geopperde ideeën over materiaaltypen en de vorm waarin die ingezet kunnen worden, later ook samen met de testresultaten, kritisch tegen het licht gehouden en vervolgstappen bepaald. De deelnemers hieraan waren vissers, technisch visserij onderzoekers, materiaaldeskundigen, producenten van pluis, studenten, visserij vertegenwoordigers, ambtenaren en vertegenwoordigers van NGO's.

- Aangezien vissers verspreid over Nederland wonen en het grootste gedeelte van de week op zee zitten, is gekozen om hen op twee manieren bij VisPluisvrij te betrekken en te informeren: online (twitter en facebook), fysiek tijdens visserij-evenementen (onder andere Holland Fisheries Event 2014, I-Sea, Visserijdagen Urk, Noordzeedagen, jongerennetwerk Visserij) en via artikelen (onder andere VisNed, natuurorganisaties, Visserijnieuws).

- Voor het verzamelen van ideeën, samen verder bouwen aan ideeën en communicatie over het project zijn ook de sites www.vispluisvrij.nl en www.dollyropefree.com ontwikkeld. Hierop konden mensen hun ideeën posten en onderling discussiëren over ingebrachte ideeën of vragen. Op de site stond verder het project beschreven, werd een filmpje getoond over het vraagstuk en werden geregeld blogs geplaatst door projectpartners over de zoektocht naar alternatieven voor pluis. 

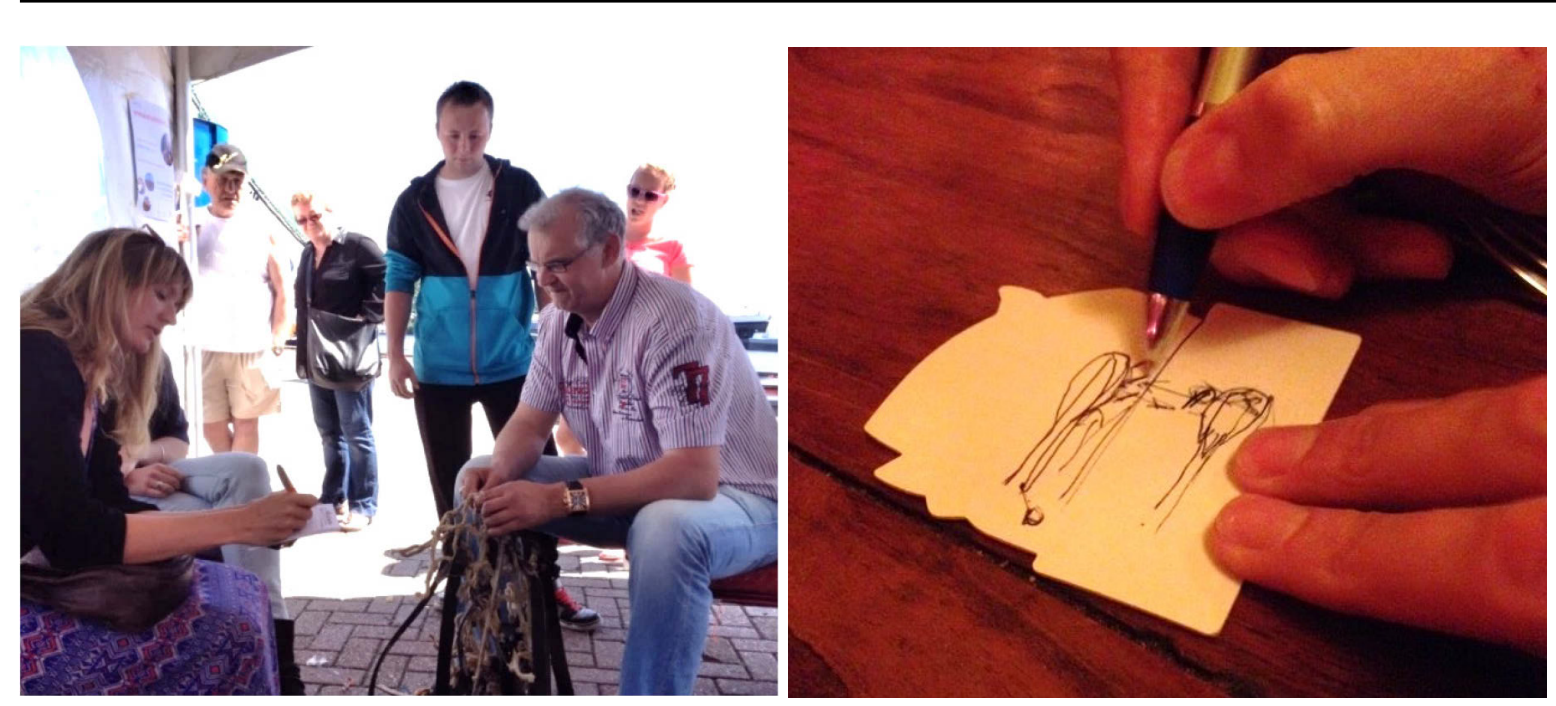

Ideeën verzamelen tijdens de Visserijdagen in Urk

Een groot idee ontstaat op een klein bierviltje
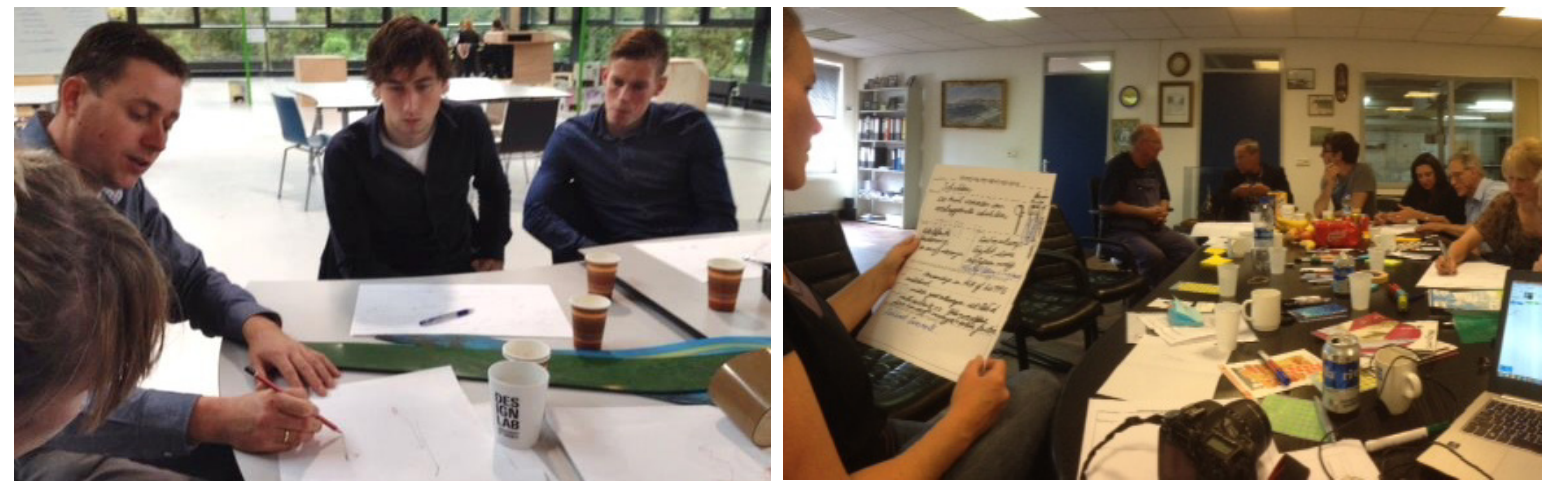

Idee- en ontwerpsessie met studenten van de TU

Startsessie VisPluisvrij

Twente (lid van S.G. Daedalus)

Figuur 3.1 Sfeerimpressie activiteiten fase 2

Foto's: W.J. Strietman.

\subsubsection{Materiaal en ontwerp}

Op basis van de expertsessies is een lijst samengesteld met de meest kansrijke materiaaltypen en ontwerpen voor de praktijktests. Voor de selectie van de potentieel meest kansrijke alternatieve materialen en ontwerpen is rekening gehouden met de volgende criteria:

- stevigheid en robuustheid

- flexibiliteit

- gewicht

- Manier waarop deze aan het netwerk te bevestigen is;

- Kostprijs;

- Beïnvloeding van de effectiviteit ('visnamigheid') van het net.

De materialen die tijdens het trechterproces benoemd zijn als kansrijke alternatieven en vervolgens getest zijn op zee kunnen worden ingedeeld in drie soorten:

1. Natuurlijke materialen:

- hout (in verschillende ontwerpen)

- natuurlijke vezels (manila, hennep en sisal)

- jakleer.

2. Biologisch afbreekbare plastics (biopolymeren) ${ }^{1}$

- PLA en PLA composieten met vlas en sisal

- TPS (Solanyl).

\footnotetext{
${ }_{1}^{1}$ Biologisch degradeerbare polymeren, ook wel biopolymeren genoemd, kunnen door middel van micro-organismen omgezet worden in $\mathrm{CO}_{2}$ en water. Vaak zijn dergelijke materialen gemaakt van zetmeel, cellulose, plantaardige oliën en/of glucose.
} 
3. Niet biologisch afbreekbare plastics

- polyurethaan

- pvc

- kunstrubber (transportband en fietsband).

Gedurende het testproces zijn, afhankelijk van het type materiaal, de volgende ontwerpen getest:

- draadvorm

- stroken

- rechthoekige flappen

- driehoekige flappen

- 'bootjesvorm'.

\subsubsection{Tests in de zeewatertank van het Visserij-innovatiecentrum en op zee}

Alle als kansrijk geachte combinaties van materialen en ontwerpen als alternatief voor regulier pluis zijn vervolgens in fase 1-6 tijdens tests in de zeewatertank van het Visserij-innovatiecentrum Zuidwest-Nederland en in de praktijk door drie kotters. Aansluitend op het project VisPluisvrij hebben vijf kotters onder coördinatie van VisNed en in samenwerking met Senbis Polymer Solutions een door Senbis ontwikkeld in zeewater degradeerbaar materiaal getest (Verroen, 2020).

Bij de tests in het Visserij-innovatiecentrum zijn alle materialen in een 33 meter lange bak met zeewater en een zandbodem getest op hun slijtvastheid. De materialen waren daarbij bevestigd aan een loopwagen die 100 x over de bak heen en weer reed. Hierdoor is elk materiaal ruim 6 kilometer over de bodem gesleept. Bij de tests op zee zijn de materialen in verschillende hoeveelheden bevestigd aan de netten (Strietman, 2020).

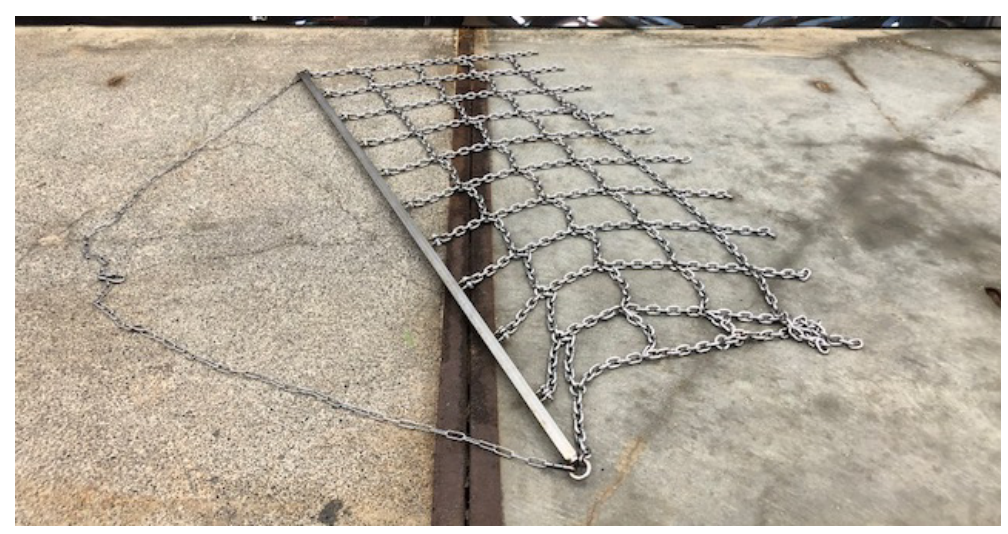

Figuur 3.2 Het apparaat waaraan de materialen bevestigd werden en over de bodem van de zeewatertank werden getrokken en waarmee de weerstand en slijtage van materialen gemeten is Foto: Johan Baaij. 
De tests op zee zijn uitgevoerd door verschillende kotters op verschillende visgronden: zandige gronden en stenige gronden. Daarbij is van elk materiaal de slijtvastheid en praktische toepasbaarheid bijgehouden en geregistreerd (figuur 3.3).
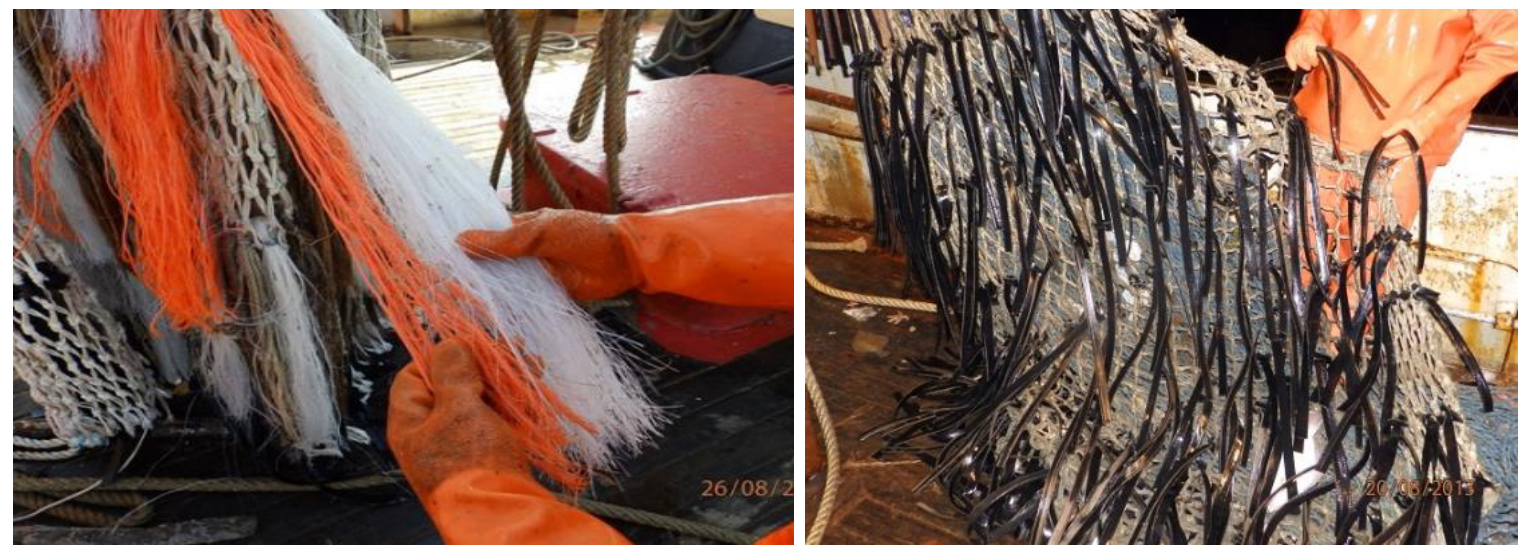

Figuur 3.3 Tests in 2013 met verschillende oplossingsvarianten qua materialen en ontwerpen: rubberen stroken (links) en PLA draden (rechts)

Foto's: K.J. Koffeman.

\subsubsection{Resultaten}

Alle individuele testresultaten zijn beschreven in de eerdere rapportages van VisPluisvrij (Strietman et al., 2013; Strietman, 2014; Strietman et al., 2015; Strietman et al., 2016; Strietman et al., 2017; Strietman, 2020) en het rapport van het aansluitende project 'Testfase Biopluis' onder coördinatie van VisNed (Verroen, 2020). Samenvattend kan per type materiaal het volgende vastgesteld worden:

\begin{tabular}{|c|c|}
\hline \multirow[t]{2}{*}{ Natuurlijke materialen } & $\begin{array}{l}\text { Natuurlijke vezels_(zoals manila, hennep en sisal) bleken niet sterk en slijtvast genoeg om } \\
\text { gebruikt te worden als alternatief voor regulier pluis. }\end{array}$ \\
\hline & $\begin{array}{l}\text { Jakleer_is ontwikkeld door Peter Koning in samenwerking met een leerlooierij in Mongolië. Dit } \\
\text { materiaal is getest in de vorm van strips op een grote kotter vanuit Stellendam. Daarbij is het } \\
\text { materiaal in kleinere hoeveelheden tussen regulier pluis gehangen en getest op stenige } \\
\text { visgronden. Op basis van die tests lijkt het materiaal voor dergelijke visgronden minder } \\
\text { geschikt (Strietman, 2020). Los van het project VisPluisvrij is door twee kotters getest op } \\
\text { zandige gronden en daar lijkt het door de geringere slijtage een kansrijk alternatief voor } \\
\text { regulier pluis. Daarbij is het ontwerp (strips) in combinatie met de sterkte van het materiaal } \\
\text { de belangrijkste reden waardoor de slijtage in vergelijking met regulier pluis substantieel } \\
\text { minder is (die immers bestaat uit draadjes die gemakkelijk loslaten). In vergelijking met } \\
\text { regulier pluis is de kostprijs van dit materiaal ongeveer drie keer zo hoog. }\end{array}$ \\
\hline $\begin{array}{l}\text { Biodegradeerbare } \\
\text { polymeren }\end{array}$ & $\begin{array}{l}\text { Een materiaal van in zeewater biologisch afbreekbaar pluis, hierna Biopluis genoemd is } \\
\text { ontwikkeld door Senbis Polymer Innovations BV. Dit materiaal is qua ontwerp vergelijkbaar } \\
\text { met regulier pluis doordat het uit draden bestaat en is gemaakt van polymeren die in zeewater } \\
\text { afbreekbaar zijn. Aansluitend op de eerste tests met dit materiaal onder de vlag van } \\
\text { VisPluisvrij zijn aansluitend onder coördinatie van VisNed in samenwerking met Senbis in } 2020 \\
\text { met een doorontwikkelde versie van dit materiaal op vijf schepen testen uitgevoerd, zowel op } \\
\text { zandige als op stenige gronden. De deelnemers waren enthousiast over de slijtvastheid en de } \\
\text { werking van dit materiaal. Omdat het een materiaal is dat nog in ontwikkeling is wordt er } \\
\text { gewerkt aan verbeteringen, bijvoorbeeld om ervoor te zorgen dat het materiaal nog beter } \\
\text { vastgeknoopt kan worden aan het net. En ook aan verbeteringen in de opslag om te } \\
\text { voorkomen dat het materiaal onder invloed van bacteriën en warmte voortijdig begint af te } \\
\text { breken. De prijs van dit materiaal ligt, net als het jakleer, ongeveer drie keer hoger dan } \\
\text { regulier vispluis. }\end{array}$ \\
\hline
\end{tabular}


Het alternatief in draadvorm was ontwikkeld en geleverd door Ymuiden Stores. Het materiaal bleek tijdens de tests sterker te zijn dan regulier pluis en werkte goed op zowel zandige als stenige gronden. PLA is op land composteerbaar en daardoor leek dit een interessante optie. Echter, omdat niet met zekerheid vast te stellen was of dit materiaal ook op zee zou afbreken, en zo ja op welke termijn, zou dit materiaal door de producent niet verkocht kunnen worden als gegarandeerd 'marien biodegradeerbaar'. Daarom is gedurende het project door de producent besloten om de ontwikkeling van dit materiaal voor deze toepassing te stoppen.

Vanuit dezelfde redenering is door de stuurgroep besloten om de PLA met vlas composiet in plaatvorm (ontwikkeld en ingebracht door Modified Materials) niet verder te testen.

TPS (Solanyl) is een materiaal dat afbreekbaar (composteerbaar) is en gemaakt van zetmeel. Dit materiaal en het ontwerp (strips) was ingebracht door Senbis. Dit materiaal bleek bij de tests op zee niet sterk genoeg: na een paar weken braken er stukken af. Daarom is besloten om dit materiaal dan ook niet verder te ontwikkelen en te testen.

Niet-biodegradeerbare polymeren
Polyurethaan. Dit is een materiaal dat niet afbreekbaar is in zee maar wel heel sterk en slijtvast, ook is het recyclebaar. Het voordeel is dat dit materiaal in allerlei gradaties van flexibiliteit geproduceerd kan worden, van heel hard en stug tot heel flexibel. Dit materiaal wordt momenteel ook op zee ingezet, bijvoorbeeld voor de (groene en rode) markeringsboeien op zee van Rijkswaterstaat. De kosten zijn relatief hoog (rond zeven keer de prijs van regulier pluis), maar het idee achter het toepassen van dit materiaal is dat het door zijn sterkte en slijtvastheid niet snel in zee terecht zal komen waardoor de kosten ook weer terugverdiend worden. Doordat het materiaal minder snel slijt en daarmee minder snel in zee terechtkomt, zou dit een duurzamer alternatief kunnen zijn voor regulier pluis. Ook is door het ontwerp (strips) de slijtage substantieel minder in vergelijking met regulier pluis die bestaat uit draadjes die gemakkelijk loslaten. Het materiaal leek op basis van de tests in fase 5 kansrijk, maar doordat de producent helaas niet meer betrokken kon zijn bij fase 6, zijn verdere vervolgtests niet meer uitgevoerd.

Kunstrubber blijkt in de vorm van strips een goed alternatief op de zandige gronden. Het voordeel van dit materiaal is dat het hergebruikt wordt nadat het voor een eerdere toepassing (fietsband, transportband) niet meer geschikt is: het krijgt op die manier in de visserij nog een tweede leven voordat het definitief als afval verwerkt wordt. Door de robuustheid en flexibiliteit van het materiaal in combinatie met het ontwerp (strips) is de slijtage substantieel minder in vergelijking met regulier pluis dat bestaat uit draadjes die gemakkelijk loslaten. De kosten hiervan zijn niet vastgelegd in de eerdere rapportages van VisPluisvrij en daardoor niet bekend.

\subsection{Het ontwikkelen van alternatieve vormen van netbescherming}

\subsubsection{Inleiding}

Tijdens het verzamelen van ideeën uit het buitenland kwam rond 2014 de tip binnen om ook eens te kijken naar een vorm van netbescherming die veel in Frankrijk wordt ingezet om de netten te beschermen tegen slijtage: een beschermingsnet met klossen. Deze is vervolgens door VisPluisvrij uit Frankrijk geïmporteerd voor tests op zee en is voor het gebruik qua ontwerp verder aangepast door de bemanning van een bij VisPluisvrij betrokken eurokotter om het nog robuuster en slijtvaster te maken. Die kotter past dit aangepaste ontwerp naar tevredenheid toe sinds 2016 (inmiddels zo'n vijf jaar).

In de originele 'Franse' versie worden touwen in een soort ruitvormen geknoopt, die om de zak van het net gedaan wordt. Op de punten waar de touwen kruisen zijn om het touw klossen bevestigd. Dit materiaal vervangt volledig het pluis op de sleeplap onder het achtereinde (de kuil) van het net.

In de aangepaste versie zijn de klossen vervangen door kabelschijfjes (restanten van gebruik bij twinrignetten) en het touwwerk omhuld met gridslangen die normaal gesproken op de pulsstrengen bevestigd zijn. In figuur 3.4 staan foto's van de originele versie en de aangepaste versie. 

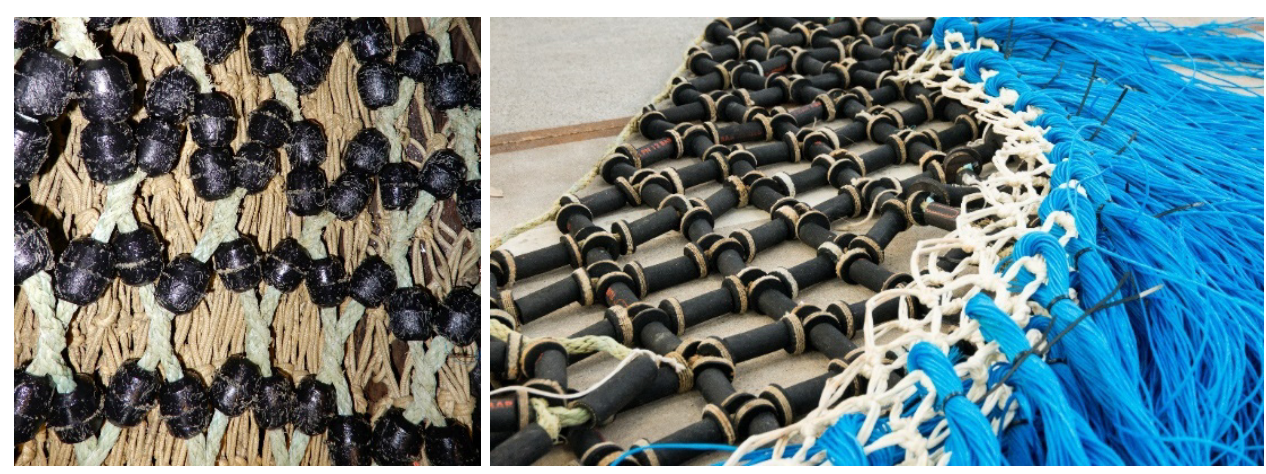

Figuur 3.4 Klossen met touwwerk aan boord van de TH10 (originele versie) en in het Innovatiecentrum (aangepaste versie), inclusief regulier pluis (blauw)

Foto's: Albert Baaij.

De twee varianten zijn in opdracht van VisPluisvrij getest voor de tongvisserij in de Noordzeekustzone in relatief ondiepe wateren (Strietman, 2020). Na de tests is de aangepaste versie in dezelfde visgronden nog steeds (mei 2021) in gebruik, naar volle tevredenheid van de schipper. Bij het vissen in diepere wateren verandert de effectiviteit van het net en wordt er overgeschakeld op sleeplappen met regulier pluis.

Volgens de schipper vangt het net met deze netbeschermingsmethode aanzienlijk minder zand doordat het netbeschermingsmateriaal goed doorspoelt; er komt dan ook haast geen zand terecht in de opvangbak. Er is in vergelijking met het gebruik van regulier pluis wel wat verlies van tong, maar de vistijd neemt toe omdat er minder vaak zand en stenen in het net achterblijven en er dus minder vaak gehaald moet worden, een tijdrovende bezigheid. Per saldo is er daardoor volgens de schipper geen verschil in tongvangsten in vergelijking met een schip dat regulier pluis gebruikt. Ook in gebruik is er tevredenheid van schipper en bemanning omdat dit materiaal minder onderhoud(stijd) vergt dan regulier pluis (Strietman, 2020).

\subsection{Het ontwikkelen van manieren om bodemcontact te verminderen}

\subsubsection{Inleiding}

Het zoeken naar alternatieve netontwerpen om bodemcontact te verminderen is de derde oplossingsrichting binnen VisPluisvrij. Het achterliggende idee is dat alternatieve netontwerpen gericht op minder bodemcontact het risico op slijtage en daarmee de noodzaak tot het gebruik van pluis kunnen verminderen.

\subsubsection{Aanpak, tests en huidige stand van zaken}

Gedurende het project zijn door experts op dit gebied tijdens bijeenkomsten verschillende soorten oplossingen onder de loep genomen en zijn als concepten verder uitgewerkt. De conclusie luidde dat er kansen lagen om deze ideeën te testen en toepasbaar te maken voor gebruik in de visserij maar dat hiervoor vervolgstappen voor nodig waren met meer betrokkenen en financiers. Bij overleg met stakeholders in Duitsland bleek, dat de overheden van Schleswig-Holstein en Niedersachsen ook aan de slag wilden gaan met oplossingen. Omdat in Nederland al de focus lag op het ontwikkelen van alternatieve materialen en ontwerpen werd in Duitsland gekozen voor deze oplossingsrichting.

Vervolgens heeft het Thünen Instititut dit onderwerp verder opgepakt met financiering vanuit het Europese Visserijfonds. Dit heeft geresulteerd in het project 'Dolly Rope Suspension' (DropS), wat gestart is in 2018 en nog lopende is. DRopS heeft tot doel een alternatief ontwerp te vinden voor boomkornetten dat elke vorm van bescherming tegen slijtage van de netten door bodemcontact 
overbodig maakt - in de veronderstelling dat bescherming tegen slijtage ook de selectiviteit van het vistuig beïnvloedt en richt zich specifiek op de garnalenvisserij in Duitse wateren.

Binnen het project wordt gewerkt aan vier verschillende soorten oplossingen om het contact van het netwerk met de zeebodem te minimaliseren (OSPAR, 2020 en Lichtenstein, 2018):

1. Het ontwikkelen van toepassingen van passief (bijvoorbeeld in de vorm van drijvers) en actief (bijvoorbeeld in de vorm van 'kites') drijfvermogen aan de achterkant van het net,

2. Het aanpassen van het ontwerp van de sleepnet door gebruik te maken van een speciale uitsnijding van het net dat resulteert in een stijgende beweging van het sleepnet of door het gebruik van ronde (span)banden om het opzwellen van de kuil te voorkomen,

3. Het ontwikkelen van manieren om de hoeveelheid sediment die door het vistuig wordt opgedwarreld te reduceren,

4. Het ontwikkelen van manieren om de hoeveelheid sediment in het sleepnet te verminderen door bijvoorbeeld het gebruik van panelen die benthos doorlaten en afvoeren of grotere mazen in de het onderste deel van de voorkant van het netwerk.

Het beoogde resultaat is om verschillende oplossingen aan te kunnen reiken aan garnalenvissers, die kunnen helpen het bodemcontact van het sleepnet te minimaliseren en geen negatief effect hebben op de vangst. Vissers kunnen dan kiezen welke (combinatie van) oplossing (en) voor hen of hun visgronden het beste werkt.

Binnen de vier oplossingsrichtingen zijn zeven opties ontwikkeld (Constanze Hammerl, 2021, pers. comm):

- De eerste twee opties zijn recentelijk getest: een aangepast zeefnet waarmee de hoeveelheid sediment in het net verminderd kan worden en speciale rollers die bedoeld zijn om de vangst van zwaar materiaal en het slepen over de zeebodem te verminderen. De laatste optie werkte niet zoals gewenst; het aangepaste zeefnet heeft veelbelovende resultaten opgeleverd.

- In 2021 worden de resterende vijf opties getest:

- een nieuw ontworpen zeefmat als alternatief voor het zeefnet

- een soort dubbele kuil waarmee de diameter van de kuil verkleind kan worden

- een ontwerp waarbij de verdeling van het drijfvermogen aangepast wordt in combinatie met bescherming tegen slijtage

- een stijgend sleepnet (ontworpen door Peter de Witt)

- een alternatief ontwerp voor de vorm van het vistuig ('straight ground gear').

\subsection{Het creëren van bewustwording en vergroting van het draagvlak voor oplossingen}

\subsubsection{Inleiding}

De vierde oplossingsrichting is gericht op het vergroten van bewustwording rondom het probleem van pluis dat in zee terechtkomt, het vergroten van support om pluis tijdens onderhoudswerkzaamheden aan boord zoveel mogelijk te verzamelen, op te slaan en in de havens in te leveren en het verspreiden van informatie over activiteiten en ontwikkelingen binnen het project VisPluisvrij.

\subsubsection{Aanpak en resultaten}

Sinds 2013 zijn door de bij dit project betrokken partijen belangrijke stappen gezet. Hieronder volgt een opsomming van de belangrijkste acties op dit gebied (Strietman et al., 2013; Strietman, 2014; Strietman et al., 2015; Strietman et al., 2016; Strietman et al., 2017 en Strietman, 2020):

- het betrekken van vissers bij het project door deelname aan de tests en het delen van ervaringen in overleggen, nieuwsberichten en andere communicatie uitingen door VisNed;

- artikelen, blogs en nieuwsberichten via de website en nieuwsbrieven van St. De Noordzee;

- informatieverspreiding via blogs en artikelen vanuit VisPluisvrij; in eerste instantie via de projectwebsite www.vispluisvrij.nl; later is deze informatie gepubliceerd op www.vistikhetmaar.nl; 
- het inzetten van de social media accounts @VisPluisvrij en de Facebookpagina

https://www.facebook.com/vispluisvrij;

- het organiseren van expert sessies vanuit VisPluisvrij;

- artikelen in Visserijnieuws;

- bijdragen aan educatief materiaal voor visserijscholen (via ProSea);

- een filmpje met uitleg over VisPluisvrij met daarin de uitnodiging om mee te denken:

http://www.youtube.com/watch?v=cO6LHOo-yRE

- bijdragen aan een Duitse tv documentaire over pluis;

- presentaties over het project en aanwezigheid bij (visserij)evenementen (o.a. Holland Fisheries Event, I-Sea, Visserijdagen in Stellendam, Den Oever en Urk, de Noordzeedagen, jongerennetwerk Visserij);

- deelname aan en input voor internationale beleidssamenwerking zoals OSPAR (pluis is opgenomen als actie in het OSPAR Marine Litter Regional Action Plan).

Daarnaast zijn de activiteiten vanuit de bij VisPluisvrij betrokken partners sinds de komst van de Green Deal Visserij voor een Schone Zee ook onderdeel geworden van een overkoepelende strategie om in gezamenlijkheid het thema visserijafval verder op te pakken (KIMO, 2021). De ambitie van de partners binnen de Green Deal Visserij voor een Schone Zee is dat al het visserijafval aan wal gebracht wordt, gemakkelijk, efficiënt ingezameld kan worden en nuttig verwerkt wordt (bij voorkeur recycling). Pluis is als één van de afvalstromen onderdeel van dit bredere thema van afvalmanagement.

Ook is als onderdeel van de Green Deal op initiatief van Adrie Vonk en Andries de Boer in samenwerking met Bek \& Verburg een initiatief gestart ('Het is wel pluis') met als doel om pluis tijdens onderhoudswerkzaamheden aan boord apart te verzamelen, in de havens in te leveren en vervolgens te recyclen. De deelnemende vissers kregen hiervoor een kleine vergoeding, die gedoneerd werd aan de KNRM (Visserijnieuws, 2015). 


\section{$4 \quad$ Conclusie en aanbevelingen}

\subsection{Inleiding}

Het project VisPluisvrij is in 2013 gestart op initiatief van VisNed, St. De Noordzee, Rijkwaterstaat en Wing met als doel om in gezamenlijkheid oplossingen te ontwikkelen waarmee het verlies van pluis in zee substantieel verminderd wordt. Het project is in eerste instantie uitgevoerd onder coördinatie van Wing en later Wageningen Economic Research. Het project bestond uit zes verschillende fasen die samen één geheel vormden. De laatste fase, fase zes, eindigde in 2018. Aansluitend is in 2020 onder coördinatie van VisNed een project gestart waarin door vijf kotters op zee aanvullende tests uitgevoerd zijn met in zeewater afbreekbare biopolymeren. Al deze resultaten vormen de basis van deze rapportage.

Tijdens de projectperiode is er gewerkt aan vier oplossingsrichtingen:

1. Het ontwikkelen van duurzame alternatieve materialen

2. Het ontwikkelen van alternatieve vormen van netbescherming

3. Het ontwikkelen van manieren om bodemcontact te verminderen

4. Het creëren van bewustwording en de vergroting van het draagvlak voor oplossingen.

De conclusies en aanbevelingen worden hieronder per oplossingsrichting besproken. Daarnaast wordt ook nader ingegaan op de Nederlandse en Europese beleidsontwikkelingen die relevant zijn voor het thema pluis, inclusief het voornemen van de Nederlandse overheid om het gebruik van regulier pluis richting 2027 geleidelijk aan uit te faseren en het gebruik van duurzame alternatieven te stimuleren.

\subsection{Het ontwikkelen van duurzame alternatieve materialen}

\subsubsection{Conclusie}

Van draad tot schubben en van afbreekbare plastics tot leer. De zoektocht naar oplossingen die minstens even effectief zijn als pluis, praktisch in het gebruik, betaalbaar en minder belastend voor het milieu, begon met een breed palet aan ideeën. Daarbij was het van belang om een goed werkend alternatief te hebben dat met name effectief is in ruige omstandigheden met een hoge slijtagegraad zoals op stenige gronden. Juist daar wordt het meeste pluis gebruikt en door slijtage verloren.

Met de kritische blik van betrokkenen binnen en buiten de sector zijn in de projectperiode meer dan twintig materialen en ontwerpen geselecteerd en getest in de praktijk.

Al vrij snel in het project werd het duidelijk dat er niet één ultieme alternatieve oplossing was die voldeed aan alle wensen, maar dat er al naar gelang de situatie één of meerdere oplossingen zijn voor verschillende typen visserij en visgronden. Zo kunnen bijvoorbeeld strips van jakleer en kunstrubber goed ingezet worden als alternatief voor regulier pluis op zandige visgronden. Het 'Biopluis' lijkt een veelbelovend alternatief dat mogelijk voor zowel zandige als stenige visgronden inzetbaar lijkt. Voor alle drie de materialen is een punt van aandacht dat de kostprijs in vergelijking met regulier pluis substantieel hoger is. Daarmee voldoen deze alternatieven niet aan de eis die bij de start van het project gesteld werd dat een alternatief materiaal qua gebruikskosten vergelijkbaar dient te zijn met regulier pluis. 


\subsubsection{Aanbeveling}

De aanbeveling aan de overheid, sectororganisaties, producenten en coöperaties is om het gebruik van duurzame alternatieven met kunstrubber, jakleer en Biopluis te stimuleren en vanuit de overheid mogelijk te maken door middel van subsidies of andere vormen van ondersteuning. Mochten er in de komende jaren andere alternatieven naar voren komen als mogelijk kansrijk dan verdient het aanbeveling dit te bespreken in een nog op te richten klankbordgroep (zie paragraaf 4.6) en van daaruit te bepalen hoe het gebruik of de ontwikkeling daarvan gestimuleerd kan worden.

\subsection{Het ontwikkelen van alternatieve vormen van netbescherming}

\subsubsection{Conclusie}

Op basis van de tests op een eurokotter met een alternatieve vorm van netbescherming bleek dat deze oplossing goed werkt bij de tongvisserij op zandige gronden in de kustzone. In vergelijking met het gebruik van regulier pluis is er wel wat verlies van tong, maar de vistijd neemt toe omdat er minder vaak zand en stenen in het net achterblijven en er dus minder vaak gehaald moet worden, een tijdrovende bezigheid. Per saldo lijken er daardoor in de kustwateren geen significante verschillen te zijn tussen deze oplossing of het gebruik van regulier pluis. Bijkomend voordeel is dat er tijdens onderhoudswerkzaamheden minder tijd besteed hoeft te worden aan het vervangen van pluis. De kosten van deze alternatieve oplossing zijn niet precies bekend aangezien de geteste versie gemaakt was van hergebruikte onderdelen van onder andere een pulstuig. De inschatting is dat de kosten van dit alternatief (materiaal, installatie en onderhoud) significant lager liggen dan bij regulier pluis.

Het is niet ondenkbaar dat dit alternatief ook goed zou werken in de garnalenvisserij in de kustzone en Waddenzee en mogelijk ook bij platvisvisserij in diepere wateren met grote kotters.

\subsubsection{Aanbeveling}

De aanbeveling is om vanuit de sector in overleg met Rijksdienst voor Ondernemend Nederland (RVO) en het ministerie van LNV te onderzoeken of vervolgtests voor deze oplossing mogelijk zijn en, zo ja, op welke wijze.

\subsection{Het ontwikkelen van manieren om het bodemcontact te verminderen}

\subsubsection{Conclusie}

Gedurende de projectperiode zijn verschillende soorten oplossingen onder de loep genomen om het bodemcontact van het net te verminderen. De conclusie luidde dat er kansen lagen om deze ideeën te testen en toepasbaar te maken voor gebruik in de visserij maar dat hiervoor vervolgstappen voor nodig waren met meer betrokkenen en financiers. Na overleg met stakeholders in Duitsland is deze oplossingsrichting daar verder opgepakt door het Thünen Instititut en heeft geresulteerd in het project 'Dolly Rope Suspension' (DropS). Binnen dit project wordt momenteel gewerkt aan verschillende oplossingen die kunnen helpen het bodemcontact van garnalennetten te minimaliseren zonder de vangst negatief te beïnvloeden (OSPAR, 2020).

\subsubsection{Aanbeveling}

Het project is nog in uitvoering en aanbevelingen worden verwacht nadat de tests zijn uitgevoerd. 


\subsection{Het creëren van bewustwording en de vergroting van het draagvlak voor oplossingen}

\subsubsection{Conclusie}

Sinds 2013 zijn door de bij dit project betrokken partijen allerlei activiteiten uitgevoerd om de bewustwording rondom het probleem van pluis en de oplossingen ervoor te vergroten. Voorbeelden hiervan zijn het betrekken van vissers door deelname aan de tests en het delen van ervaringen in overleggen, informatieverspreiding en kennisdeling via websites, nieuwsartikelen, presentaties over het project en aanwezigheid bij (visserij)evenementen zoals Holland Fisheries Event.

De bij VisPluisvrij betrokken partners hebben zich ervoor ingezet om binnen de Green Deal Visserij voor een Schone Zee (KIMO, 2021) acties op te zetten met als doel de verzameling en opslag van afval aan boord (inclusief pluis) en de afgifte ervan in havens te verbeteren. Binnen de Green Deal is ook op initiatief van Adrie Vonk en Andries de Boer in samenwerking met Bek \& Verburg een initiatief gestart: 'Het is wel pluis'. Dat initiatief heeft als doel om pluis tijdens onderhoudswerkzaamheden aan boord apart te verzamelen, in de havens in te leveren en vervolgens te recyclen (Visserijnieuws, 2015).

\subsubsection{Aanbeveling}

De aanbeveling aan de voormalige projectpartners van VisPluisvrij is om het thema pluis en de oplossingen ervoor te blijven adresseren binnen de Green Deal. Daarbij gaat het enerzijds om het doorzetten van bewustwordingsactiviteiten en anderzijds de inname, afgifte en recycling van pluisafval te blijven stimuleren en monitoren.

\subsection{Aansluiting op relevante beleidsontwikkelingen}

De komende jaren spelen er een aantal belangrijke beleidsontwikkelingen die raken aan het gebruik van pluis en de inzet van alternatieven. Hieronder worden die nader toegelicht.

\section{Kaderrichtlijn Mariene Strategie: beoogde uitfasering van pluis}

Alle genomen stappen om duurzamere alternatieven te ontwikkelen zijn extra van belang omdat er door de Nederlandse overheid in het nieuwe programma van maatregelen van de Kaderrichtlijn Mariene Strategie een voorstel gedaan is dat gericht is op een uitfasering van het reguliere vispluis in 2027: 'Het streven is om de inzet van alternatieve oplossingen te stimuleren en het gebruik van regulier pluis geleidelijk uit te faseren tot het jaar 2027' (Rijksoverheid, 2021a). Ook in het concept Programma Noordzee staat deze uitfasering expliciet benoemd. Om deze uitfasering mogelijk te maken wordt er in het voorstel voor de programmaperiode (die duurt van 2022 tot 2027) ingezet op het financieel aantrekkelijker maken van duurzamere alternatieven en het vergroten van de bekendheid ervan (Rijksoverheid, 2021b).

\section{Single Use Plastics Richtlijn (EU)}

Ander belangrijk nieuw (aankomend) overheidsbeleid is de Europese Single Use Plastics Richtlijn (European Commission, 2019) en daarbinnen de invoering van de zogeheten Uitgebreide Producenten Verantwoordelijkheid (UPV) voor onder andere plastic houdend vistuig. Deze nieuwe wetgeving wordt uiterlijk 31 december 2024 ingevoerd; de komende periode wordt de invulling hiervan verder uitgewerkt.

Door de komst van deze richtlijn zal naar verwachting de focus en stimulans in het zoeken naar oplossingsrichtingen meer bij de producenten van visnetten, -tuigen en pluis komen te liggen, wat weer tot nieuwe inzichten en/of innovaties kan leiden. Deze verschuiving is ook van belang omdat producenten een cruciale rol hebben bij de benodigde transitie. 


\section{Standaardisatie traject (Nederland en EU)}

Ook loopt er een Europees traject om te komen tot het ontwikkelen van een standaard voor circulair design van vistuigen en netten (VisNed, 2020). Aangezien pluis in meerdere landen wordt toegepast zouden Europees-brede standaarden voor het ontwerp en toepassing van netbescherming zoals pluis een gelijk speelveld creëren. Een dergelijk traject zou kunnen betekenen dat er eisen worden gesteld aan materialen die bedoeld zijn om slijtage aan de netten te voorkomen en gebruikt kunnen worden als alternatief voor regulier pluis. De verdere doorontwikkeling van Biopluis of andere duurzame alternatieve materialen en alternatieve vormen van netbescherming zou wat dit betreft ondergebracht kunnen worden in dat traject, waarbij de internationale component meteen geborgd is.

\section{OSPAR Regional Action Plan}

Pluis is een onderwerp dat in OSPAR verband via het Regional Action Plan geadresseerd wordt (OSPAR, 2021). Hiervan zal een nieuwe versie verschijnen. In afstemming met betrokken uit Nederland biedt het opnemen van acties en maatregelen in de nieuwe versie van het Regional Action Plan on Marine Litter van OSPAR mogelijkheden om dit onderwerp internationaal verder op te pakken.

\subsubsection{Aanbeveling}

Aangezien er binnen Nederland en Europa meerdere beleidstrajecten lopen of gaan lopen die raken aan het thema pluis, inclusief de intentie van de Nederlandse overheid om het gebruik van regulier pluis tot uit te faseren is het zaak om tussen nu en 2027 een alternatief of meerdere alternatieven te ontwikkelen en paraat te hebben. Deze dienen betaalbaar te zijn en de eigenschappen hebben die gesteld worden aan het materiaal. Partijen die een belangrijke rol hebben om dit mogelijk te maken zijn met name de (potentiële) producenten van dergelijke materialen, de Coöperatieve Inkoop Verenigingen (CIV's) en vissers. Andere belangrijke partijen zijn overheid (Ministerie van LNV, Ministerie van I\&W en Rijkswaterstaat), ngo's (St. De Noordzee) en onderzoek (Wageningen University \& Research). Aanbevolen wordt om met deze betrokkenen een klankbordgroep op te richten die tot doel heeft een strategie op te stellen en uit te voeren om deze transitie mogelijk te maken zodat de uitfasering richting 2027 soepel verloopt.

Aangezien pluis in meerdere Europese landen wordt toegepast zouden Europees-brede lessen en voorwaarden aan materialen die bedoeld zijn om slijtage aan de netten te voorkomen (en gebruikt kunnen worden als alternatief voor regulier pluis) voor vissers en producenten een gelijk speelveld creëren. De verdere doorontwikkeling van Biopluis of andere duurzame alternatieven zou wat dit betreft ondergebracht kunnen worden in een Europees brede aanpak en/of project, aansluitend op de eerdergenoemde lopende initiatieven vanuit bijvoorbeeld OSPAR en de EU. 


\section{Literatuur en websites}

Boonstra, M., E. van Galen en F. van Hest (2021). Goed op weg naar een schone Noordzee. Online: https://s3-eu-west-1.amazonaws.com/noordzee/app/uploads/2021/02/18072727/Stichting-DeNoordzee-Goed-op-weg-naar-een-schone-Noordzee-2021.pdf

European Commission (2019). RICHTLIJN (EU) 2019/904 VAN HET EUROPEES PARLEMENT EN DE RAAD van 5 juni 2019 betreffende de vermindering van de effecten van bepaalde kunststofproducten op het milieu. Online: https://eur-lex.europa.eu/legalcontent/NL/TXT/PDF/?uri=CELEX:32019L0904\&from=EN\%20=\%20de\%20SUP

KIMO, 2021. Green Deal Visserij voor een Schone Zee. Online:

https://www. kimonederlandbelgie.org/projecten-2/green-deal-visserij-voor-een-schone-zee/

Lichtenstein, U. (2018). Reduction of plastic waste from the brown shrimp fishery through gear modifications (DRopS). Online: https://www.thuenen.de/en/of/projects/fisheries-and-surveytechnology/reduction-of-plastic-waste-from-the-brown-shrimp-fishery-through-gear-modificationsdrops/

OSPAR, 2020. OSPAR scoping study on best practices for the design and recycling of fishing gear as a means to reduce quantities of fishing gear found as marine litter in the North-East Atlantic. Online: https://www. OSPAR.org/documents? $=42718$

OSPAR, 2021. Action Plan for Marine Litter. Online: https://www.ospar.org/work-areas/eiha/marinelitter/regional-action-plan

Rijksoverheid (2021a). Ontwerp Mariene Strategie Deel 3 voor het Nederlandse deel van de Noordzee 2022-2027 (KRM-programma van maatregelen). Online:

https://platformparticipatie. $n l /$ nationalwaterprogramma/ontwerp +nwp/relevante+documenten $+n$ wp+ontwerp/default.aspx\#folder=1917246

Rijksoverheid (2021b). Ontwerp Programma Noordzee 2022 - 2027. Online:

https://www.rijksoverheid.nl/binaries/rijksoverheid/documenten/rapporten/2021/03/18/4ontwerp-programma-noordzee-2022-2027/4-ontwerp-programma-noordzee-2022-2027.pdf

Strietman, W.J., A. Kruft en K.J. Koffeman (2013). Een alternatief voor pluis. Online:

https://vistikhetmaar.nl/app/uploads/2019/08/Eindrapportage-VisPluisVrij-fase-1-1.pdf

Strietman, W.J. (2013). Pluis in de Waddenzee - Een inschatting van de hoeveelheid pluis die via de garnalenvisserij jaarlijks in de Waddenzee terechtkomt. Wing, Wageningen.

Strietman, W.J. (2014). Op weg naar een pluisvrije zee. Online:

https://vistikhetmaar.nl/app/uploads/2019/08/Eindrapportage-VisPluisVrij-fase-2.pdf

Strietman, W.J. en A. Kruft (2015). Eindrapport VisPluisvrij. Online:

https://vistikhetmaar.nl/app/uploads/2019/08/Eindrapportage-VisPluisVrij-fase-3.pdf

Strietman, W.J. en A. Kruft (2016). Eindrapport VisPluisvrij fase IV. Online:

http://vistikhetmaar.nl/app/uploads/2019/08/Eindrapportage-VisPluisVrij-fase-4.pdf

Strietman, W.J. en A. Kruft (2017). Eindrapport VisPluisvrij fase V. Online:

https://vistikhetmaar.nl/app/uploads/2019/08/Eindrapportage-VisPluisVrij-fase-5.pdf 
Strietman, W.J. (2020). Eindrapport VisPluisvrij fase 6. Online:

https://vistikhetmaar.nl/app/uploads/2020/01/Eindrapportage-VisPluisVrij-fase-6.pdf

Verroen, S.L. (2020). Praktijktesten in zeewater afbreekbaar 'Biopluis'. Urk: Visned.

VisNed, 2020. Recycling als criterium bij het ontwerp van visnetten. Online:

https://www.visned.nl/vissers-voor-schone-zee/NEN-SUP-visnetten-recycling-circulair

Visserijnieuws (2015). Visserijnieuws (2015). 'Het is wel pluis' op Texel. Online:

https://www.visserijnieuws.nl/nieuws/9210-het-is-wel-pluis-op-texel 
Wageningen Economic Research Postbus 29703

2502 LS Den Haag

T 0703358330

Ecommunications.ssg@wur.nl

www.wur.nl/economic-research

Wageningen Economic Research RAPPORT

2021-058
De missie van Wageningen University \& Research is 'To explore the potential of nature to improve the quality of life'. Binnen Wageningen University \& Research bundelen Wageningen University en gespecialiseerde onderzoeksinstituten van Stichting Wageningen Research hun krachten om bij te dragen aan de oplossing van belangrijke vragen in het domein van gezonde voeding en leefomgeving. Met ongeveer 30 vestigingen, 6.800 medewerkers (6.000 fte) en 12.900 studenten behoort Wageningen University \& Research wereldwijd tot de aansprekende kennisinstellingen binnen haar domein. De integrale benadering van de vraagstukken en de samenwerking tussen verschillende disciplines vormen het hart van de unieke Wageningen aanpak. 



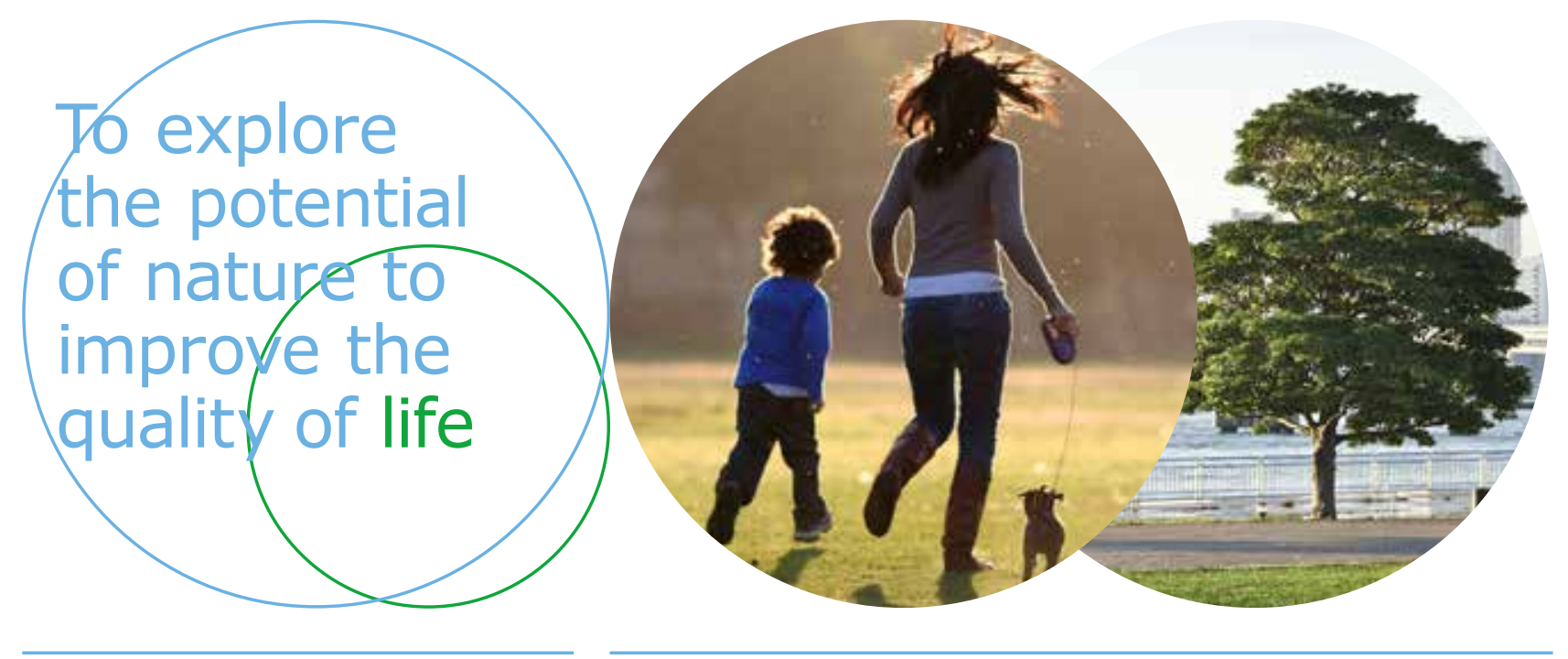

Wageningen Economic Research Postbus 29703

2502 LS Den Haag

T 0703358330

E communications.ssg@wur.nl www.wur.nl/economic-research

Rapport 2021-058

ISBN 978-94-6395-838-7
De missie van Wageningen University \& Research is 'To explore the potential of nature to improve the quality of life'. Binnen Wageningen University \& Research bundelen Wageningen University en gespecialiseerde onderzoeksinstituten van Stichting Wageningen Research hun krachten om bij te dragen aan de oplossing van belangrijke vragen in het domein van gezonde voeding en leefomgeving. Met ongeveer 30 vestigingen, 6.800 medewerkers ( $6.000 \mathrm{fte}$ ) en 12.900 studenten behoort Wageningen University \& Research wereldwijd tot de aansprekende kennisinstellingen binnen haar domein. De integrale benadering van de vraagstukken en de samenwerking tussen verschillende disciplines vormen het hart van de unieke Wageningen aanpak. 